Article

\title{
Employment and Education-Occupation Mismatches of Immigrants and their Children in the Netherlands: Comparisons with the Native Majority Group
}

\author{
Yassine Khoudja \\ European Research Centre on Migration and Ethnic Relations, Utrecht University, 3584 CH Utrecht, The Netherlands; \\ E-Mail: y.khoudja@uu.nl
}

Submitted: 28 February 2018 | Accepted: 21 May 2018 | Published: 30 July 2018

\begin{abstract}
This study examines the labor market integration of immigrants and their children in the Netherlands focusing on employment and over- and underqualification. Using data from the first wave of the Netherlands Longitudinal Life-Course Study (NELLS), the analysis shows disadvantages in employment probabilities for men and women from different foreign origin groups compared to the Dutch majority even after accounting for differences in human capital. Ethnic differences in employment probabilities are lower, but still visible, when comparing only respondents who obtained post-secondary education in the Netherlands. Further, first-generation immigrant men from Turkey and Morocco are at higher risk of being overeducated than Dutch majority men whereas this is not the case for second generation men and first- and secondgeneration minority women. Substantial ethnic difference in the likelihood of being undereducated are not prevalent. Having a foreign compared to a Dutch degree is related to lower labor market outcomes, but this negative relation is more pronounced for women than for men. Finally, there is some indication that overeducation is somewhat less common in the public sector than in the private sector, but minorities do not benefit more from this than the Dutch majority.
\end{abstract}

\section{Keywords}

employment; immigrant integration; overeducation; public sector; returns to education; the Netherlands; undereducation

\section{Issue}

This article is part of the issue "The Race for Highly-Skilled Workers", edited by Neli Demireva (University of Essex, UK) and Ivana Fellini (University of Milano Bicocca, Italy).

(C) 2018 by the author; licensee Cogitatio (Lisbon, Portugal). This article is licensed under a Creative Commons Attribution 4.0 International License (CC BY).

\section{Introduction}

Immigrants' economic success is often considered to be one of the key conditions for a successful integration into the receiving-society. Nevertheless, many immigrant groups, especially those with a non-Western origin, are often disadvantaged in the European labor markets. In the Netherlands, Turks and Moroccans are two of the most disadvantaged groups (Crul \& Doomernik, 2003). They are less likely to be employed, more likely to work in low-paid jobs, jobs with temporary contracts (Witteveen \& Alba, 2017) and non-prestigious positions (Gracia, Vázquez-Quesada, \& van de Werfhorst, 2016) than the Dutch majority.
The ethnic disadvantage of Turks and Moroccans in the Dutch labor market is often explained by their lower educational achievements compared to the Dutch majority (Becker, 1975; Bevelander \& Veenman, 2004). But typically, substantial ethnic gaps in employment rates remain even once educational achievements are accounted for (Heath, Rothon, \& Kilpi, 2008). One of the reasons for these ethnic disadvantages may be that immigrants face lower marginal returns for their education than the native majority population (Chiswick \& Miller, 2008,2009 ). Studies in other countries have shown that education received abroad or prior to immigration is less rewarded in terms of finding employment or earnings than education obtained in the receiving country (Fried- 
berg, 2000). In line with this observation is that immigrants are also more likely to experience mismatches between their education and the occupational level of their current job than the native majority population (Aleksynska \& Tritah, 2013). Overeducation means working in a position that requires education below one's own highest achieved educational degree, whereas undereducation means having a lower education than required for one's occupational position. Overeducated employees may feel insufficiently challenged and unsatisfied with their occupational situation (Fleming \& Kler, 2008). Furthermore, while earning more than those lower educated in the same occupation, they still earn less than their equally educated counterparts in jobs that match their education level (Hartog, 2000). Undereducated employees earn less than appropriately educated individuals doing the same job (Hardoy \& Schøne, 2014). Ethnic differences in the occurrence of over- and undereducation may, therefore, corroborate the ethnic stratification of society. Education-occupation mismatches can also be viewed as an inefficient use of human capital on the societal-level. Overeducated individuals could be more productive in jobs that require more professional skills. Undereducation implies a lost opportunity given that individuals with high abilities appear to have not received the appropriate level of education.

Using the first wave of the Netherlands Longitudinal Life-Course Study (NELLS), this study examines ethnic gaps in labor market outcomes in the Netherlands with the Dutch majority as a reference group. Two recent papers have also used the NELLS to compare labor market outcomes of second-generation Turks and Moroccans in the Netherlands (Gracia et al., 2016; Witteveen \& Alba, 2017). Both papers show that once differences in human capital are accounted for, second generation Turks and Moroccans are disadvantaged at early stages of labor market trajectories (i.e., employment and employment conditions) but less disadvantaged when it comes to their occupational prestige measured by the International Socio-Economic Index (ISEI).

This article also looks at ethnic gaps in employment, though for the first and second generation. Its main contribution to the earlier studies is its focus on ethnic gaps in overeducation and undereducation. The analysis will pay particular attention to the role of returns to education of foreign degrees compared to Dutch degrees for ethnic gaps in labor market outcomes, addressing the question whether foreign degrees are differently related to labor market outcomes between varying origin groups. In addition, the study will examine whether ethnic patterns in education-occupation mismatches differ between the public and the private sector. Where sample size allows it, I distinguish between the first and second generation in the analysis as causes for disadvantages in the labor market may vary between these two groups (Portes \& Zhou, 1993). Furthermore, analyses will be conducted separately for men and women as earlier studies have shown substantial differences in immigrants' labor market trajectories and occupational choices by gender (Baker \& Benjamin, 1997; Blau, Kahn, Moriarty, \& Souza, 2003).

\section{Theoretical Background}

\subsection{Immigrants in the Netherlands}

The two largest immigrant groups in the Netherlands from non-Western countries are Turks and Moroccans. Including the second generation, there were about 400,000 Turks and 389,000 Moroccans in the Netherlands in 2016 and, together, they make up about 5\% of the Dutch population (Huijnk \& Andriessen, 2016). Turks and Moroccans arrived in the Netherlands over the last couple of decades (starting in the 1960s) as work and family migrants. Most of them arrived as low-educated workers to fill in low-skilled occupations in a booming economy. The low socio-economic background of those immigrants is still reflected today in their disadvantaged labor market position and the lower educational achievement of their children compared to children with Dutchorigin parents (van de Werfhorst \& van Tubergen, 2007; Witteveen \& Alba, 2017). Even though support for traditional norms are also relatively strong among Turkish and Moroccan immigrants, second generation women tend to perform somewhat better on the labor market than their male counterparts, particularly among Moroccans (Crul \& Doomernik, 2003). There are also important differences between Turks and Moroccans in the Netherlands. Most notably, the Turkish community is often described as more cohesive than the Moroccan one (Crul \& Doomernik, 2003; Huijnk \& Andriessen, 2016). Turks participate more in ethnic organizations and have more coethnic ties than Moroccans (Michon \& Vermeulen, 2013). Perhaps as a consequence of the dense ethnic network, Turks are somewhat less proficient in Dutch than Moroccans, and their children lack behind in terms of educational attainment compared to children from the other Non-Western immigrant groups (Huijnk \& Andriessen, 2016). On the labor market, the Turks' dependence on co-ethnic ties may impede employment chances and access to jobs with higher occupational status (Lancee, 2010), which may ultimately result in a higher occurrence of overeducation compared to the other ethnic minority groups.

Two other large non-Western immigrant groups in the Netherlands are Surinamese and Antilleans. These immigrants started to arrive in the Netherlands as postcolonial migrants about a decade earlier than the guestworkers and still migrate today (though in substantially smaller numbers than in the 1960s and 70s). Surinamese and Antilleans in the Netherlands tend to have on average higher educational levels and are more likely to work in higher-skilled jobs than Turks and Moroccans, but they still do worse than the Dutch majority in the educational system and on the labor market (Huijnk \& Andriessen, 2016). Additionally, to these four main immigrant groups, 
the Netherlands also saw an influx of refugees from diverse non-Western backgrounds in the 1990s and 2000s (Dourleijn \& Dagevos, 2011). Finally, there is also a large group of Western immigrants. However, this group is less in the focus of societal and academic debates, partly because it is perceived as economically less disadvantaged and culturally more similar to the native Dutch than the other immigrant groups. Therefore, Western immigrants provide analytically a useful comparison to the other immigrant groups.

\subsection{Returns to Education for Immigrants and Their Children}

Ethnic gaps in labor market outcomes are often explained by compositional differences in human capital between ethnic groups. In the Netherlands, the disadvantaged position on the labor market of non-Western minority groups, including those with a Turkish or Moroccan national origin, is often explained by their lower educational level compared to the native majority group. Other human capital characteristics often discussed in the literature on immigrant's labor market performance are skills in the language of the receiving society and naturalization (Dustmann \& Fabbri, 2003; Hainmueller, Pietrantuono, Aktas, Balaban, \& Kurer, 2017). Both of these factors increase immigrants' labor market opportunities over and above their educational level (Bevelander \& Veenman, 2006).

A higher likelihood of overeducation among immigrants may be caused by difficulties in the international transferability of foreign educational degrees (Chiswick \& Miller, 2008; Hardoy \& Schøne, 2014). Migration often results in a loss of value of educational degrees completed in the origin country as qualifications and skills acquired in the origin country's educational system may be difficult to apply in the host-society due to language barriers or lack of knowledge of the labor market. A loss of value may also be due to origin-country differences in the quality of education (Li \& Sweetman, 2014), which is often perceived to be higher in Western than in NonWestern countries (Friedberg, 2000). Ethnic gaps in labor market outcomes may also be explained by less resourceful social networks of immigrants compared to the native majority (Lancee, 2010). Finally, employers might require minorities to have greater educational levels in order to 'compensate' for either statistical discrimination or a taste for discrimination by the employer, resulting in a higher likelihood of immigrants to be unemployed or overeducated (Andriessen, Nievers, \& Dagevos, 2012; Hardoy \& Schøne, 2014).

Undereducation follows somewhat different dynamics than employment or overeducation. Talented or highly motivated individuals who were not successful in the educational system can prove their worth on the labor market and get promoted as recognition for their talents, landing them in positions above their educational level. Positive selection of immigrants on unob- served characteristics such as cognitive ability or motivation may lead to a higher rate of undereducation among immigrants than among the native majority (Aleksynska \& Tritah, 2013). However, this effect should be more pronounced for individuals that have accumulated work experience in the receiving society and had opportunities to prove that their actual abilities are higher than their formal educational level would suggest.

\subsection{Minorities in Public Sector Jobs in the Netherlands}

Since the 1980s, the Dutch government has implemented policies aimed at improving the labor market integration of immigrants, particularly those from Turkey, Morocco and the former Dutch colonies Suriname and the Antilles (Doomernik, 1998). Even though these policies have repeatedly changed since, some evidence suggests that certain policy measures have led to an increase in public sector employment among immigrants, especially second-generation Turks and Moroccans (Groeneveld, 2011; Tesser \& Veenman, 1997). Employment in the public sector is often held to higher standards and tends to be subject to stricter procedures in filling vacant positions than employment in the private sector. This suggests that being employed by the government protects to some extent from the ethnic disadvantage often experienced in the private sector. Field experiments suggest that public sector employers are often less likely to discriminate against minority applicants than private employers (Zschirnt \& Ruedin, 2016). However, the Dutch government's efforts in improving ethnic minorities' labor market position have also been heavily criticized for their ineffectiveness (Vasta, 2007). In line with this criticism, Groeneveld (2011) has shown that ethnic minorities are more likely to (voluntarily) leave public sector jobs than native Dutch, suggesting that they are less satisfied with their employment in the public sector than native Dutch.

\section{Data and Methods}

\subsection{Data}

I use the first wave of the NELLS for the analysis (de Graaf, Kalmijn, Kraaykamp, \& Monden, 2010a). Data collection for the first wave took place between December 2008 and May 2010 with a break of two months in July and August 2009. Respondents of Moroccan and Turkish origin, based on respondents' and their parents' country of birth, were intentionally oversampled. The response rate of the survey was $52 \%$ (56\% for Dutch, $50 \%$ for Turkish and $46 \%$ for Moroccans). Women, older respondents, the urbanized areas and the Southern regions of the Netherlands are over-represented whereas the West is under-represented (de Graaf et al., 2010a). Weights are provided to adjust for these deviations. As there are only very few Moroccans and Turks living in rural municipalities, this group was not included in the sample. The sam- 
ple contains observations of 5312 respondents aged 15 to 49 .

I distinguish between five origin groups in the analysis (though due to small sample sizes I must pool groups for some analyses): Dutch, Turks, Moroccans, Non-Western, and Western. Turks and Moroccans are further classified into first and second generation. Respondents who were born abroad with at least one foreign-born parent are classified as a first-generation migrant unless they immigrated to the Netherlands before they were four years old, which is the age at which children enter school in the Netherlands. Respondents who were born in the Netherlands to at least one foreign-born parents or who arrived before they reached school age are classified as second generation. Due to small sample sizes, the first and second generation have to be pooled for respondents with Non-Western or Western origin. Hence, any conclusions with respect to generational differences do not apply to these groups. Western origin refers to all European countries (excluding Turkey), U.S., Canada, Australia, New Zealand, Japan, and Indonesia (this is a small group of probably ethnic Dutch from former Dutch Indonesia). The group with a non-Western origin contains individuals from all other countries including the former Dutch colonies Suriname and the Dutch Antilles. Any references to respondents with Non-Western origin in the following do not refer to the Turks and Moroccans in the sample.

Observations of retired respondents and students are excluded from the analysis. The remaining number of observations in the analytic sample is 4229 , of which 2063 are native majority Dutch, 610 first generation Moroccan, 279 second generation Moroccan, 608 first generation Turks, 321 second generation Turks, 169 first and second generation of Non-Western origin, and 179 first and second generation of Western origin.

\subsection{Measures}

The main dependent variables are employment, overqualification, and underqualification.

I compare employed individuals to individuals who are not employed. The latter group includes individuals without a job who are searching for a paid work and those not searching for a job.

For education-occupation mismatches, there are different ways to measure mismatches between workers' education and the qualifications required for their occupation. The biggest challenge of any measure is to get a correct estimation of the qualifications or skills required for a specific occupation (for a discussion of different measures, see Verhaest \& Omey, 2006). This study uses the mean measure of the so-called realized matches approach. In this approach, the required level of education is estimated by the actual distribution of workers' educational level within an occupation. I estimate the required educational level at the 3-digit level ISCO-08 scale. Required education is estimated on the basis of the years of education of employees with a completed Dutch education as this is the reference point likely to be used by Dutch employers (Nielsen, 2011). The mean method classifies individuals as overeducated (undereducated) when their years of education is 1 standard deviation above (below) the mean years of education within their occupation.

By definition, overeducation is mainly a concern for higher educated individuals whereas undereducation is more relevant for individuals with low educational achievements. Individuals with no or very little education are not at risk of being overqualified whereas individuals with high educational achievements are not at risk of undereducation. Many studies exclude the groups that are not at risk from the analysis. To maximize the sample size, I keep these observations in the analytic sample but control for years of education to account for those who are not at risk of being classified as over- or undereducated and for ethnic difference in educational achievement. Years of education is also an important indicator of human capital and therefore relevant to account for when examining ethnic gaps in employment.

I create a dummy variable that measures whether the highest education was completed at least partially in the Netherlands (0) or abroad (1). Another dummy indicates whether employed respondents reported working in the private sector (0) or in the public sector (1).

Ethnic gaps in education-occupation mismatches may be due to initial occupational misplacements of the immigrant workers shortly after their arrival. Overeducated immigrants might get promoted once their actual skills and knowledge are recognized by their employers or as they get more familiar with the labor market and find a job that matches their educational level. In contrast, the ethnic gap in undereducation might increase once work experience in the Dutch labor market is accounted for if immigrants are positively selected on unobserved characteristics. I only have a proxy of work experience in the Dutch labor market based on either the years since the respondent left full-time education (if the respondent is native Dutch or obtained the highest educational degree in the Netherlands) or years since the respondent's migration to the Netherlands (if the respondent is non-Dutch and obtained the highest degree abroad). I call this proxy exposure to Dutch labor market and use it as a control in the analysis of educationoccupation mismatches. For the analysis of employment, I only use years since migration (instead of exposure to Dutch labor market) as a control because the sample may include respondents who were not active in the labor market since they have left education or arrived in the Netherlands. Some of the variance due to work experience and years since migration may already be explained by age as older individuals have more work experience than younger individuals. Hence, I control for age and age square. I measure respondents' Dutch language skills (based on the interviewer's assessment), using a dichotomous variable that distinguishes between respondents 
who are proficient in Dutch (0) and those who are not (1). Dutch citizenship is also measured with a dummy variable that distinguishes between Dutch citizens (0) and Non-Dutch citizens (1). Urban areas tend to provide a wider range of employment opportunities than rural areas. Therefore, finding a (better matched) job is more likely for those living in larger cities than those living in smaller cities or in the countryside. As immigrants are over-represented in urban areas (and under-represented in rural areas), I also account for living in a big or medium city compared to a small city or rural area.

\subsection{Analytic Strategy}

I begin the analysis by presenting distributional traits of the relevant variables. Means/proportions and standard deviations of all included variables are presented for the total sample in Table 1. Means/proportions of selected variables are also shown by national origin group and generation (e.g., education-occupation mismatches) in Table 2.

In the explanatory analysis, I run multivariable logistic regression models and use Average Marginal Effects (AME) to compare outcomes between the different origin groups.

First, I examine gaps between origin groups in employment and over- and undereducation with the Dutchorigin group as the reference accounting. Note that all analyses of over- and undereducation focus only on respondents in employment. ${ }^{1}$ In a second step, I restrict the sample to respondents who received (academic or vocational) tertiary education in the Netherlands to examine ethnic gaps in employment rates and overeducation for those with comparable educational credentials. In the third part of the analysis, I examine an interaction between origin and having received the highest education abroad. This analysis focuses on first generation immigrants who are most likely to have received education abroad. Finally, I examine the interaction effect of origin and working in the public sector on the likelihood of being overeducated and undereducated. Due to the potential endogeneity of Dutch language proficiency, citizenship, and living in a city, I estimate two models for each analysis: A basic model that only accounts for age, age square, years of education, and years since migration/exposure to Dutch labor market and an extensive model that additionally accounts for Dutch language problems, citizenship, and urbanity. The presentation of the results will focus on the extensive models and only refer to the basic models if their estimates show any substantial differences.

Weights are applied in all regression analyses to adjust for deviances of the sample from the national distribution in sex, age, region, and urbanization increasing the comparability between the origin groups (de Graaf et al., 2010b). All models are estimated with robust standard errors. Analyses are conducted separately for men and women as studies have shown that labor market behavior is strongly shaped by gender (Baker \& Benjamin, 1997; Blau et al., 2003). Observations with missing values $(\mathrm{N}=28)$ are listwise-exclude from the analysis. Results are depicted as graphs (Figures 1 to 10), with full models included as tables in the annex (Tables A1 to A3).

\section{Results}

\subsection{Descriptive Results}

Table 1 shows descriptive results. The share of undereducated and overeducated in the sample are both $14 \%$. Table 2 shows that there are substantial differences between the different groups on all variables. Employment ranges from $90.3 \%$ for the Dutch majority to $58.9 \%$ for first-generation immigrant Moroccans. The differences are somewhat reduced after excluding respondents who are not active in the labor market (e.g., homemaker), which is likely due to the large share of Moroccan and Turkish women that focus on domestic work instead of paid employment. Nonetheless, employment is still substantially lower for Turkish, Moroccan and Non-Western immigrants and their children even after excluding respondents who are not active in the labor market.

Mismatches in the level of workers' education and their occupation seem to be most common among firstgeneration immigrants. The level of education and occupation matches correctly for $76 \%$ of the Dutch majority, $77 \%$ of the second-generation Moroccans, $73 \%$ of the second-generation Turks, $63 \%$ of first-generation Moroccans and $61 \%$ of first-generation Turks. First and second-generation Turks and Moroccans are more often undereducated than overeducated whereas for the other groups the opposite is the case. Among first generation Turks and Moroccans, the share of undereducated is notably higher than among the other groups.

\subsection{Explanatory Results}

\subsubsection{Ethnic Gaps in Employment and Over- and Undereducation}

Figure 1 presents the employment gaps between different minority groups and the Dutch majority. Minority groups are less likely to be employed across gender and generation with the exception of first generation Turkish men who are almost as likely to be employed as Dutch majority men. The estimated employment gap for Western origin men is also not significant but still lies at about $8 \%$. For the first generation, the ethnic gaps in

\footnotetext{
${ }^{1}$ One could argue that selection into employment may bias results of the overeducation and undereducation models. I, therefore, also estimated models with Heckman correction (more details about the model specification provided in the annex). Results of this robustness test do not indicate a strong selection bias (see Figures A2 and A3) and give uncertainty about the correct instruments and the sensitivity of Heckman models to mis-specification, I present the main results with standard logit-AME models.
} 
Table 1. Descriptive statistics.

\begin{tabular}{|c|c|c|c|c|}
\hline & $\mathbf{n}$ & Range & Proportion/Mean & Std. Dev. \\
\hline Employed of total labor force ( $0=$ inactive/unemployed $)$ & 4228 & $0 / 1$ & 0.79 & \\
\hline Employed of active labor force $(0=$ unemployed $)$ & 3619 & $0 / 1$ & 0.92 & \\
\hline Education-occupation mismatches & 3338 & $0-2$ & & \\
\hline Undereducated & & & 0.14 & \\
\hline Correctly matched & & & 0.72 & \\
\hline Overeducated & & & 0.14 & \\
\hline Highest education obtained abroad & 4143 & $0 / 1$ & 0.19 & \\
\hline (Ref. education obtained in the NL) Post-secondary education & 4143 & $0-2$ & & \\
\hline At most secondary education & & & 0.72 & \\
\hline Post-secondary education abroad & & & 0.03 & \\
\hline Post-secondary education in the NL & & & 0.24 & \\
\hline Public sector job $(0=$ private sector job $)$ & 3339 & $0 / 1$ & 0.16 & \\
\hline Female $(0=$ male $)$ & 4229 & $0 / 1$ & 0.53 & \\
\hline Years of education & 4228 & $0-23$ & 11.62 & 3.42 \\
\hline Age & 4229 & $16-49$ & 34.27 & 7.29 \\
\hline Lives in big or medium city ( $0=$ lives in town or rural area) & 4229 & $0 / 1$ & 0.58 & \\
\hline Lives with partner ( $0=$ lives alone) & 4228 & $0 / 1$ & 0.71 & \\
\hline Kids under age 12 in household $(0=$ no $)$ & 4229 & $0 / 1$ & 0.53 & \\
\hline No Dutch citizenship ( $0=$ Dutch citizenship) & 4229 & $0 / 1$ & 0.12 & \\
\hline Fluent Dutch $(0=$ not fluent Dutch) & 4228 & $0 / 1$ & 0.87 & \\
\hline
\end{tabular}

Note: Unweighted descriptive results.

Table 2. Proportions/means on key variables by national origin and generation.

\begin{tabular}{|c|c|c|c|c|c|c|c|}
\hline & $\begin{array}{l}\text { Native } \\
\text { majority }\end{array}$ & $\begin{array}{l}\text { Moroccan } \\
\text { 1st gen }\end{array}$ & $\begin{array}{l}\text { Moroccan } \\
\text { 2nd gen }\end{array}$ & $\begin{array}{l}\text { Turkish } \\
\text { 1st gen }\end{array}$ & $\begin{array}{l}\text { Turkish } \\
\text { 2nd gen }\end{array}$ & $\begin{array}{l}\text { Non-Western } \\
\text { (1st and } \\
\text { 2nd gen) }\end{array}$ & $\begin{array}{l}\text { Western } \\
\text { (1st and } \\
\text { 2nd gen) }\end{array}$ \\
\hline $\begin{array}{l}\text { Employed of total labor force } \\
(0=\text { inactive/unemployed })\end{array}$ & 0.90 & 0.59 & 0.74 & 0.66 & 0.75 & 0.70 & 0.82 \\
\hline $\begin{array}{l}\text { Employed of active labor force } \\
\qquad(0=\text { unemployed })\end{array}$ & 0.96 & 0.86 & 0.90 & 0.87 & 0.86 & 0.84 & 0.94 \\
\hline \multicolumn{8}{|l|}{ Education-occupation mismatches } \\
\hline Undereducated & 0.10 & 0.22 & 0.14 & 0.25 & 0.18 & 0.12 & 0.14 \\
\hline Correctly matched & 0.76 & 0.63 & 0.77 & 0.61 & 0.73 & 0.74 & 0.65 \\
\hline Overeducated & 0.14 & 0.15 & 0.09 & 0.14 & 0.09 & 0.14 & 0.21 \\
\hline Years of education & 12.42 & 10.00 & 11.62 & 10.26 & 11.31 & 11.83 & 13.00 \\
\hline $\begin{array}{l}\text { Highest education obtained abroad } \\
(0=\text { education obtained in the } \mathrm{NL})\end{array}$ & 0.01 & 0.46 & 0.03 & 0.57 & 0.03 & 0.38 & 0.27 \\
\hline \multicolumn{8}{|l|}{ Post-secondary education } \\
\hline At most secondary education & 0.67 & 0.08 & 0.76 & 0.83 & 0.82 & 0.66 & 0.56 \\
\hline Post-secondary education abroad & 0.003 & 0.08 & 0.01 & 0.08 & 0.003 & 0.14 & 0.10 \\
\hline Post-secondary education in the NL & 0.33 & 0.10 & 0.23 & 0.09 & 0.18 & 0.20 & 0.34 \\
\hline $\begin{array}{l}\text { Public sector job } \\
\qquad(0=\text { private sector job })\end{array}$ & 0.15 & 0.18 & 0.17 & 0.15 & 0.15 & 0.16 & 0.16 \\
\hline Number of observations & 2063 & 610 & 279 & 608 & 321 & 169 & 179 \\
\hline
\end{tabular}

Note: Unweighted descriptive results. 


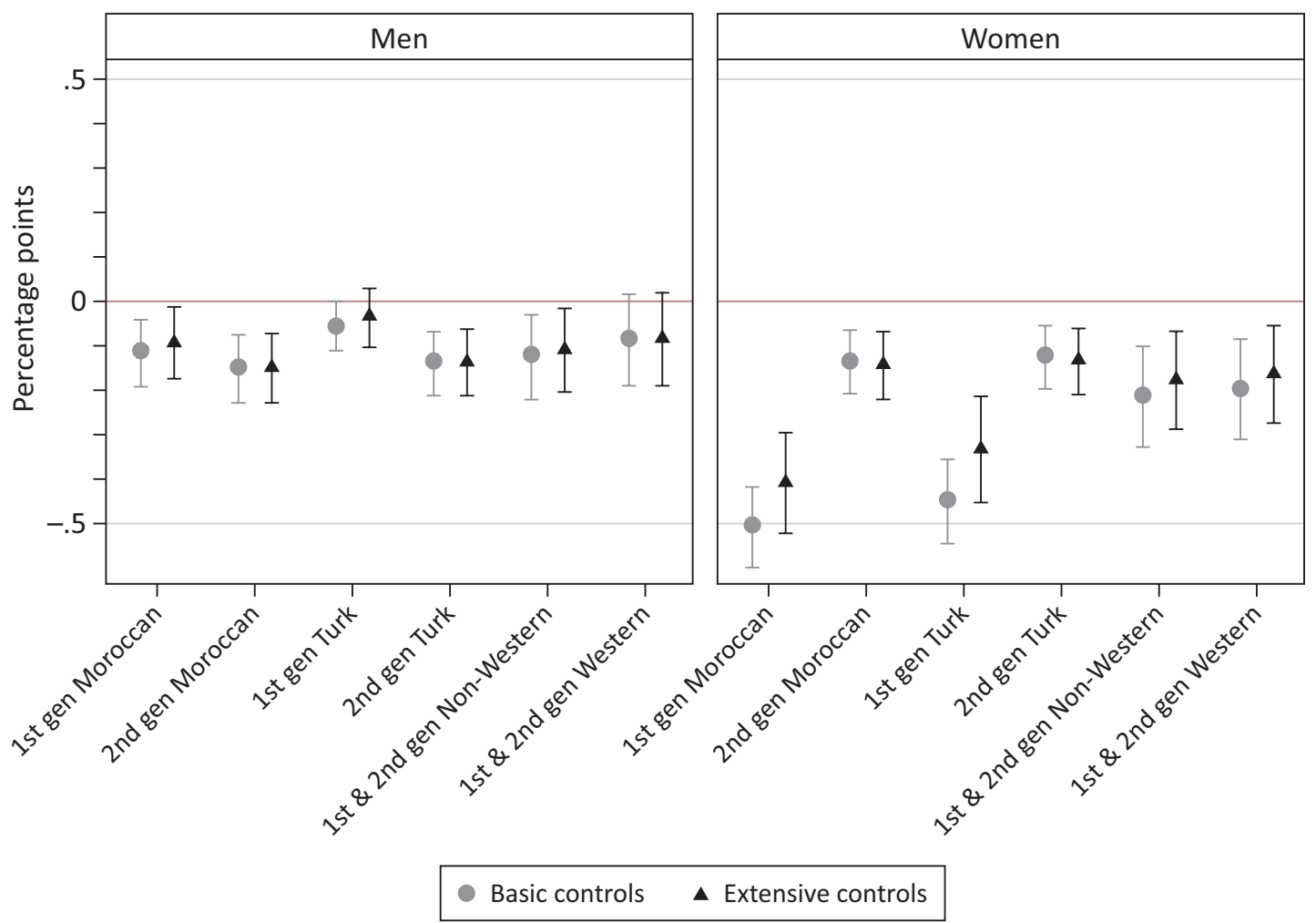

Figure 1. Estimated employment gaps between different origin groups and the Dutch majority with $95 \%$ confidence interval (c.i.) (see Table A1). Basic controls: for age, age square, years of education, years since migration. Extensive controls: basic controls, urbanity, Dutch language problems, and Dutch citizenship. All models are weighted.

employment are higher for women than for men. Firstgeneration Moroccan and Turkish women are about 50 and 45 percentage points less likely to work than native Dutch women when accounting for the basic controls. ${ }^{2}$ Adding citizenship, Dutch language skills, and urbanity to the model decreases this difference, which still remains larger than for any other group. The estimated ethnic employment gap in the second generation is about as large for women as for men.

Figure 2 shows ethnic gaps in overeducation. Firstgeneration Moroccan and Turkish men are 10 and 5 percentage points more likely to be overeducated than Dutch majority men. For women, the likelihood of being overeducated does not differ substantially by origin or generation.

Figure 3 shows that there are no substantial differences in undereducation between Moroccan, Turkish, and Dutch majority men. Men with Non-Western origin are $4 \%$ less likely to be undereducated than Dutch majority men. Among women, only first-generation Moroccans are significantly less likely (about $7 \%$ ) to be undereducated than the Dutch majority. This suggests that the higher share of undereducation of Turks and Moroccans shown in the descriptive results are rather due to the lower educational level of this groups than to a positive selection of the immigrants.

\subsubsection{Returns to Post-Secondary Education Completed in the Netherlands}

For the analysis in the following section, I constrain the sample to respondents who have completed (vocational or academic) tertiary education in the Netherlands. This allows me to test whether there is ethnic parity in labor market outcomes once ethnic minorities obtained their educational degree from a Dutch educational institution. Figure 4 shows that there are no significant employment gaps between ethnic minority and Dutch majority men with a Dutch tertiary education. However, confidence intervals are rather large and estimated differences are still around $10 \%$ for most groups except first generation Moroccans and Turks. Second-generation Turkish women and first- and second-generation non-Western and Western women who have obtained their tertiary education in the Netherlands have lower employment rates than Dutch majority women (though the difference is not significant at the $5 \%$ level for the Non-Western and Western origin women). Figure 5 shows that for those with a

\footnotetext{
${ }^{2}$ As additional analyses show (see Figure A1 and Table A4), ethnic disadvantage in women's employment is substantially lower, especially for first and second generation Moroccan women, when excluding economically inactive women (i.e. those who are unemployed and not searching for employment) from the analysis. In contrast, ethnic gaps in men's employment are less sensitive to the exclusion of economically inactive respondents. This suggests that the ethnic differences in women's employment maybe partly due to more traditional family structures-with husbands focusing on paid work and wives on domestic work -in some ethnic minority groups than in the majority group.
} 


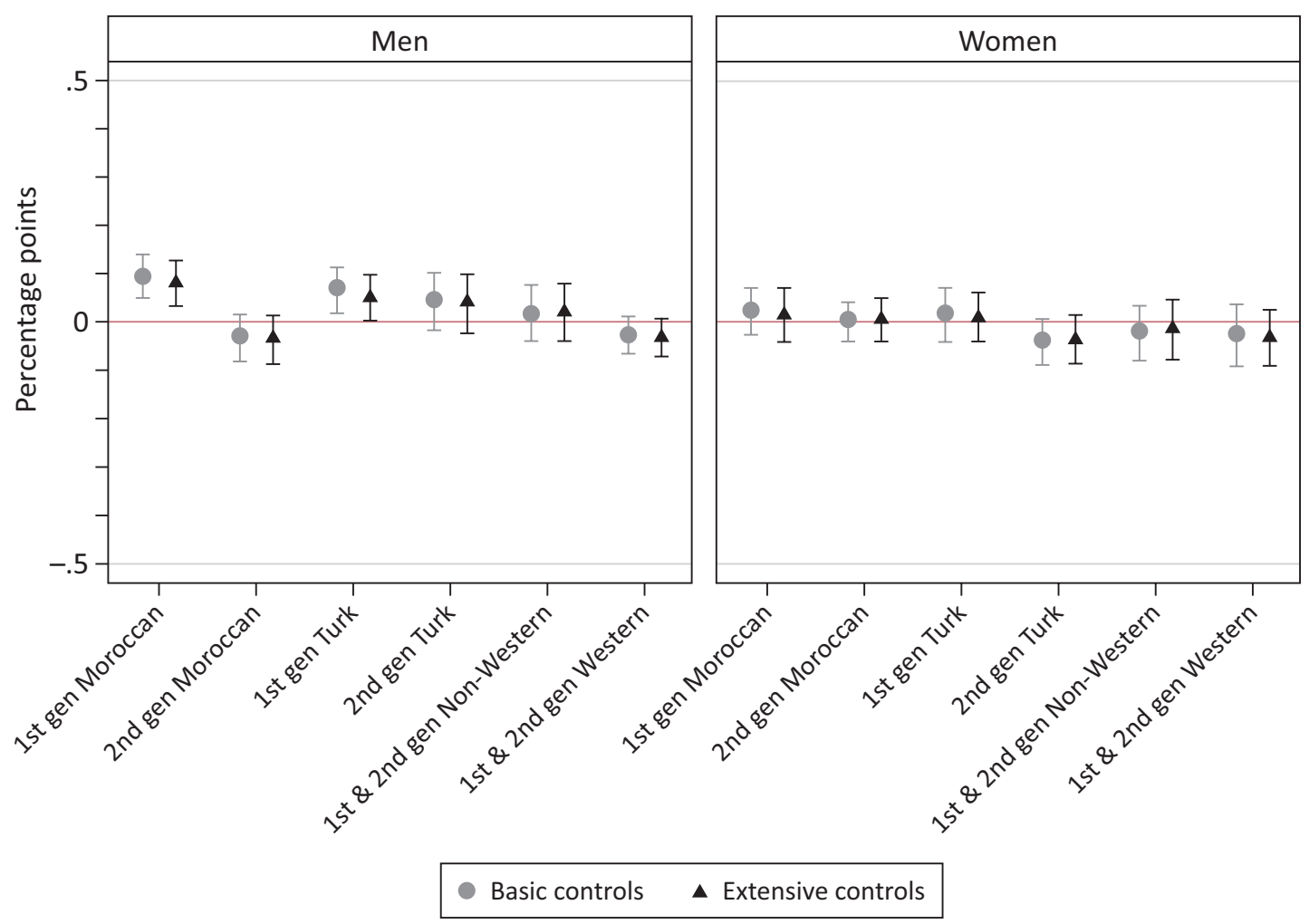

Figure 2. Estimated gaps in overeducation between different origin groups and Dutch majority with 95\% (c.i.) (see Table A2). Basic controls: for age, age square, years of education, exposure to Dutch labor market. Extensive controls: basic controls, urbanity, Dutch language problems, and Dutch citizenship. All models are weighted.

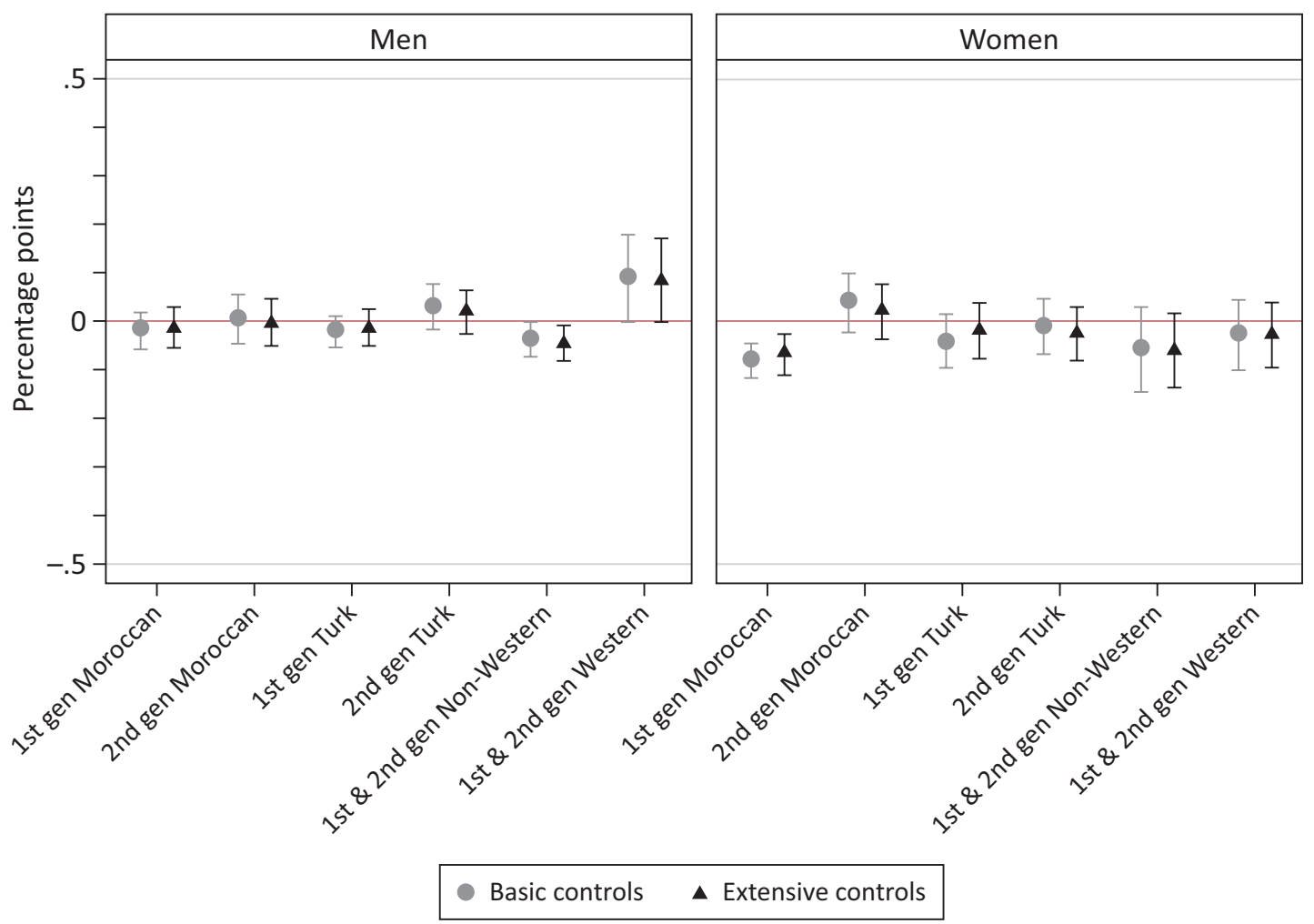

Figure 3. Estimated gaps in undereducation between different origin groups and Dutch majority with $95 \%$ (c.i.) (see Table A3). Basic controls: for age, age square, years of education, exposure to Dutch labor market. Extensive controls: basic controls, urbanity, Dutch language problems, and Dutch citizenship. All models are weighted. 


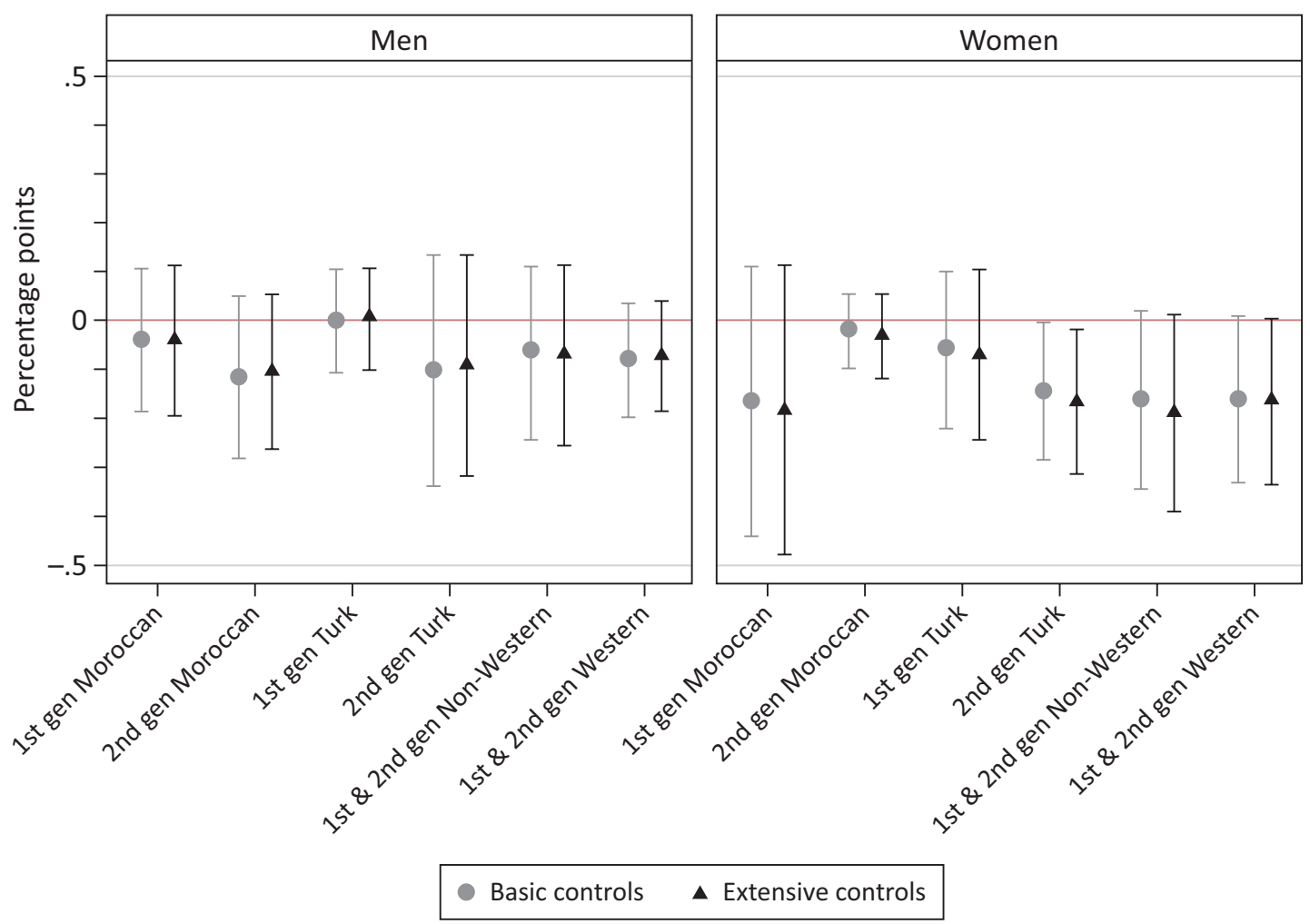

Figure 4. Estimated gaps in employment between different origin groups and the Dutch majority for respondents who completed tertiary education in the Netherlands with 95\% (c.i.). Basic controls: age, age square, exposure to Dutch labor market. Extensive controls: basic controls, urbanity, Dutch language problems, and Dutch citizenship.
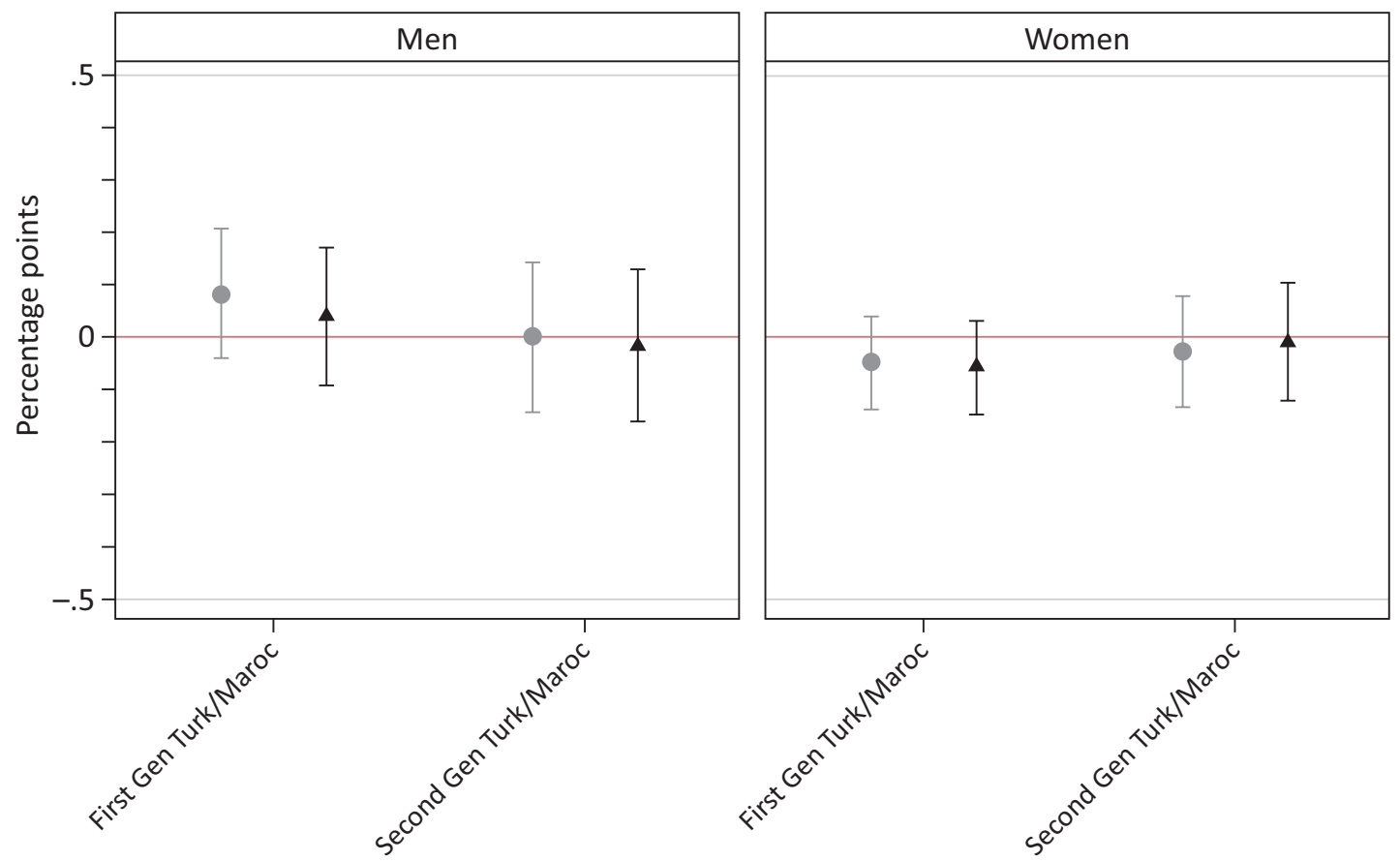

Basic controls $\Delta$ Extensive controls

Figure 5. Estimated gaps in overeducation between different origin groups and the Dutch majority for respondents who completed tertiary education in the Netherlands with $95 \%$ (c.i.). Basic controls: for age, age square, exposure to Dutch labor market. Extensive controls: basic controls, urbanity, Dutch language problems, and Dutch citizenship. 
Dutch tertiary education, the likelihood of being overeducated does not differ by origin or generation for either men or women.

\subsubsection{Returns to Education: Foreign Degrees vs. Degrees Obtained in the Netherlands}

I now investigate how having obtained the highest degree abroad compared to having received the highest degree in the Netherlands is associated with labor market outcomes and whether there are differences in these associations between origin groups. Second generation Turks and Moroccans are excluded from this analysis (or pooled together with non-Western) as only a small number have a foreign degree. Figure 6 shows that a degree from abroad is not strongly associated with employment for men from most of the groups. Only first generation Moroccan men have an about $8 \%$ lower likelihood of being employed if they obtained their highest degree abroad and not in the Netherlands though this difference is not significant at the $5 \%$-level. Having a degree from abroad is associated with a substantially lower employment probability for first generation Turkish and Non-Western origin women but not for native Dutch and first generation Moroccan women.
Figure 7 shows the relation of having a foreign degree with overeducation for the different origin groups. Firstgeneration Moroccan men show an about $10 \%$ higher likelihood of being overeducated if they have obtained their highest educational degree abroad and not in the Netherlands. For the other origin groups, a degree from abroad is not strongly related to the likelihood of being overeducated. For women, the probability of being overeducated increases with a foreign degree for Dutch majority and first-generation Moroccan women (though for the latter the difference is not significant at the 5\%level with extensive controls). Given the low sample size of employed native Dutch women with foreign highest degrees $(N=12)$, the relatively large estimated effect size should not be overinterpreted.

Having a foreign degree is also not strongly related to undereducation for most origin groups as can be seen in Figure 8. Only Dutch majority men and secondgeneration Turks, Moroccans and Non-Western men are somewhat less likely to be undereducated if they have a foreign compared to a Dutch degree. First generation Turkish women with a foreign degree show a somewhat lower likelihood to be undereducated than those with a Dutch degree in the basic controls model but the difference disappears once additional controls are added.

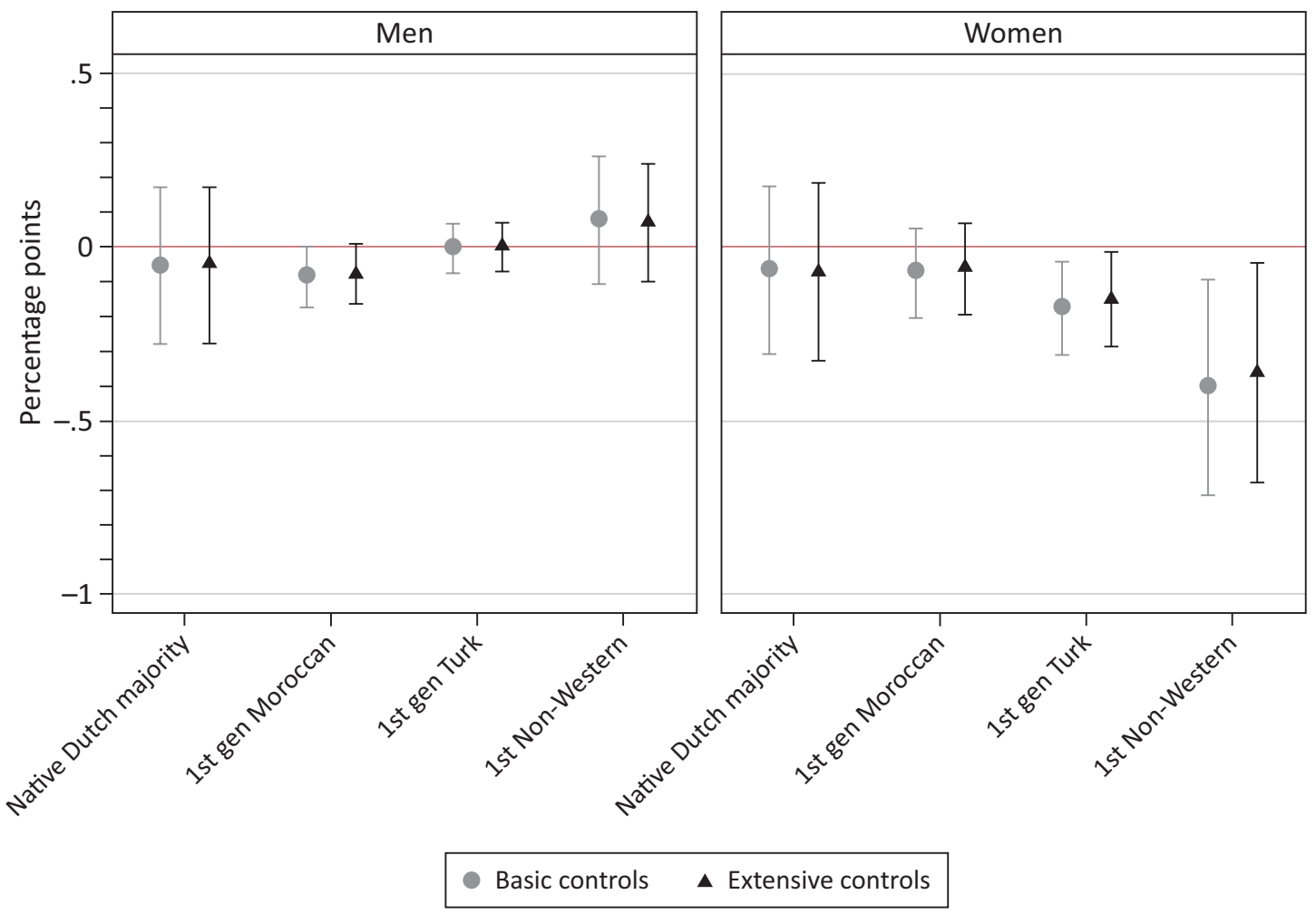

Figure 6. AME of highest education received abroad (compared to highest education received in the Netherlands) on being employed by origin and gender. Basic controls: for age, age square, exposure to Dutch labor market, education received abroad, interaction: education received abroad and national origin. Extensive controls: basic controls, urbanity, Dutch language problems, and Dutch citizenship. Note: the $y$-scale is larger than in the other figures due to the confidence interval of first generation non-Western women. 


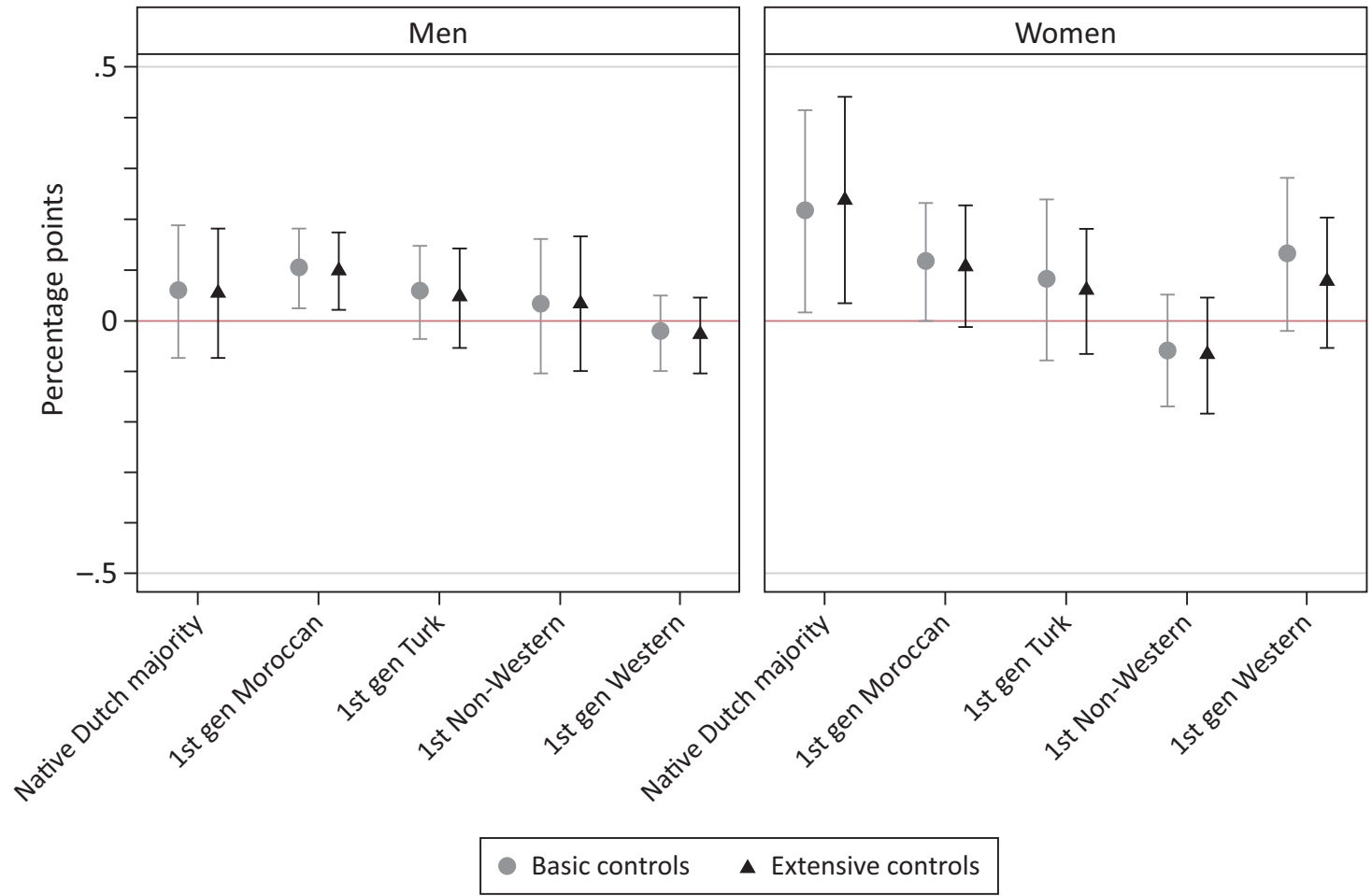

Figure 7. AME of highest education received abroad (compared to highest education received in the Netherlands) on overeducation by origin and gender. Basic controls: for age, age square, exposure to Dutch labor market, education received abroad, interaction: education received abroad and national origin. Extensive controls: basic controls, urbanity, Dutch language problems, and Dutch citizenship.
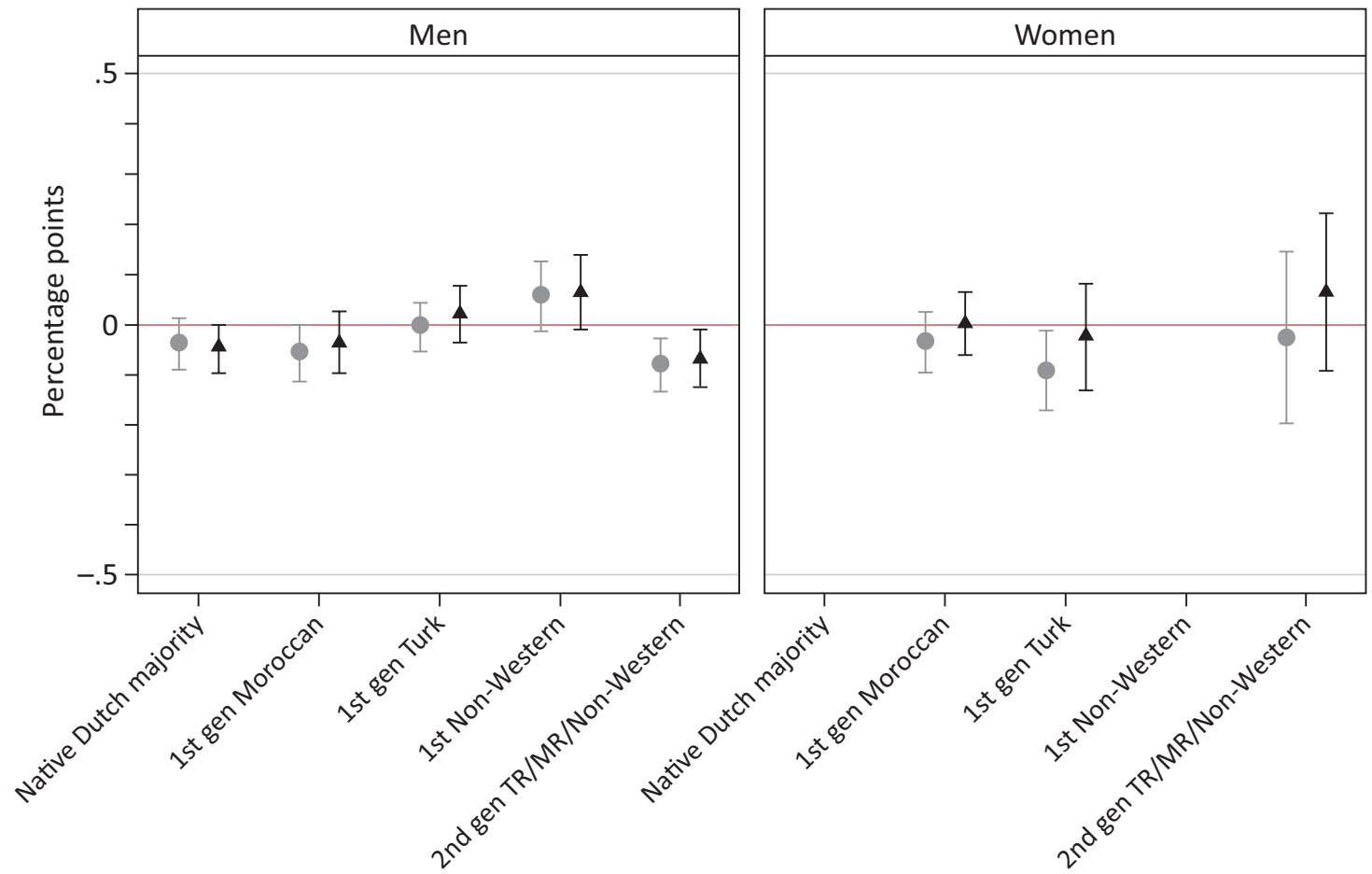

Basic controls $\Delta$ Extensive controls

Figure 8. AME of highest education received abroad (compared to highest education received in the Netherlands) on undereducation by origin and gender. Basic controls: for age, age square, exposure to Dutch labor market, education received abroad, interaction: education received abroad and national origin. Extensive controls: basic controls, urbanity, Dutch language problems, and Dutch citizenship. Coefficient estimates for the Dutch majority and first generation Non-Western immigrant women missing due to small sample sizes. 


\subsubsection{Public Sector Jobs}

In the final analysis, I examine whether being employed in a public sector job reduces the probability of a mismatch between individuals' educational and occupational level. Figure 9 presents the results for overeducation. For men, the findings show that native Dutch and Non-Western origin men are about 5 and 9 percentage points less likely to be overeducated in the public than in the private sector. Dutch majority women, first generation Turkish women, and women with origin in Western countries are also less likely to be overeducated in public sector jobs than in private sector jobs even though these differences are not significant at the 5\%-level. For the other groups, especially Turkish and Moroccan men and Moroccan women, the data does not provide much evidence for such a protective effect of the public sector.

In Figure 10, I examine whether working in the public sector is also related to the likelihood of being undereducated. There is little evidence for such a relation among male and female native Dutch. However, secondgeneration Moroccan men and first-generation Turkish men are about $5 \%$ less likely to be undereducated in the public sector than in the private sector. Ethnic minority women are about $10 \%$ more likely to be undereducated in public than in private sector jobs even though the difference is only significant for first-generation Mo- roccan women (and first-generation Turkish women in the model with only basic controls).

\section{Conclusion}

This study examined to what extent minorities with different national origins are disadvantaged in the Dutch labor market compared to the Dutch majority focusing on employment and mismatches between workers' education level and the occupation skill level required for their job.

First-generation migrants and second-generation minorities with Turkish and Moroccan background experience clear disadvantage in finding employment, even after accounting for compositional differences in human capital, which is in line with plenty of earlier studies in the Netherlands as well as in other European countries (Heath et al., 2008). The ethnic employment gaps are reduced but remain substantial, especially for women, when comparing only individuals with tertiary education. This means that some form of social exclusion, let it be ethnic discrimination by employers or the lack of access to important social and cultural resources, creates higher barriers to employment for ethnic minorities than for the native Dutch.

Ethnic gaps in education-occupation mismatches are less pronounced than gaps in employment but still ob-

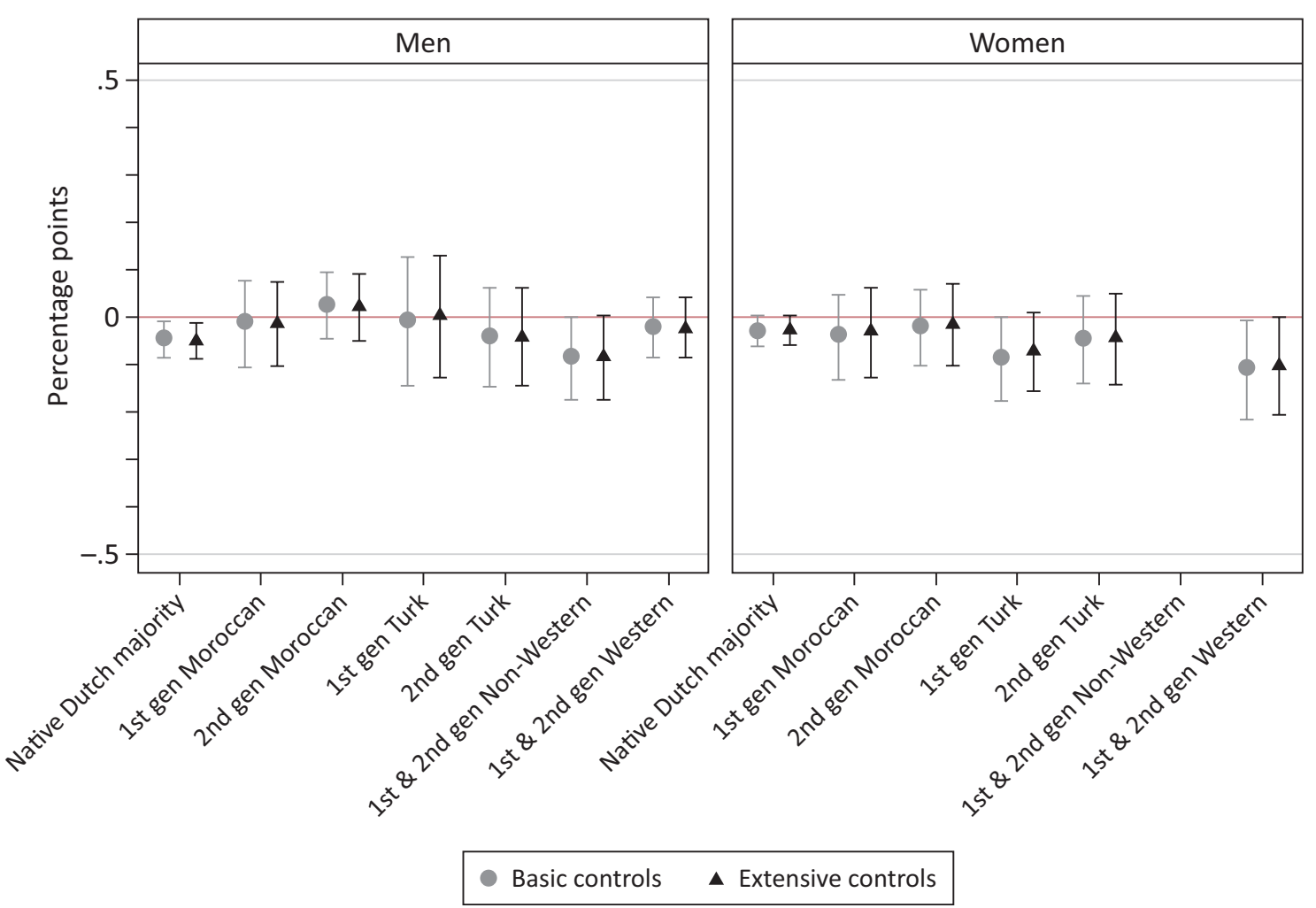

Figure 9. AME of working in the public sector (compared to working in the private sector) on overeducation by origin. Basic controls: for age, age square, exposure to Dutch labor market, public sector job, interaction: public sector job and national origin. Extensive controls: basic controls, urbanity, Dutch language problems, and Dutch citizenship. Estimates for Non-Western women missing due to small sample size. 


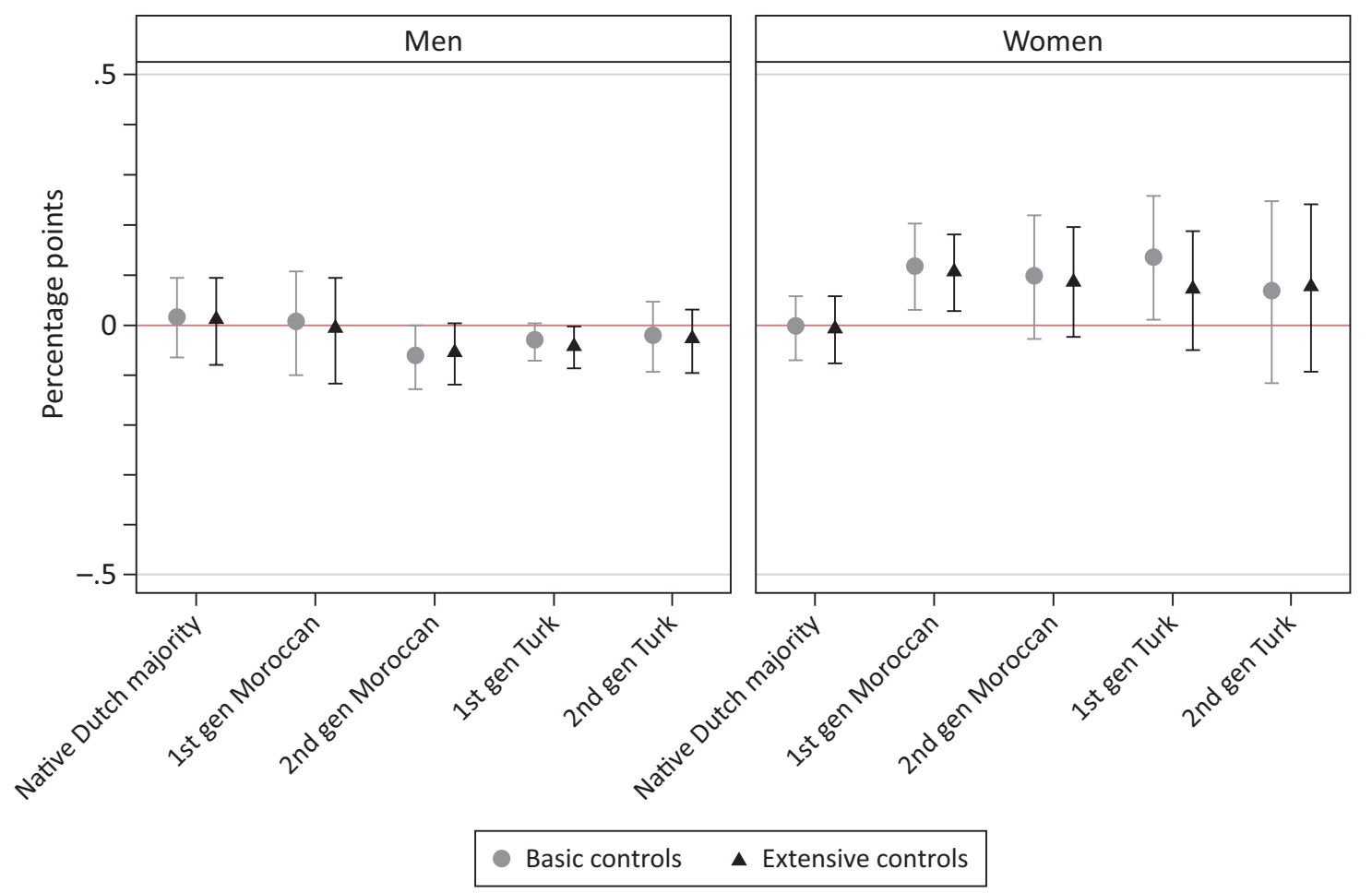

Figure 10. AME of working in the public sector (compared to working in the private sector) on undereducation by origin. Basic controls: for age, age square, exposure to Dutch labor market, public sector job, interaction: public sector job and national origin. Extensive controls: basic controls, urbanity, Dutch language problems, and Dutch citizenship. Coefficient estimates for 1st and 2nd generation Western and Non-Western individuals missing due to small sample size.

servable for the first generation. However, contrary to the expectation, there were no clear differences in the probability of being overeducated between Turks and Moroccans. Both, first-generation Turkish and Moroccan men, are more likely to be overeducated than Dutch majority men, which suggests difficulties in the transferability of their educational credentials to the Netherlands. This could be the result of highly educated immigrants turning to the low-skill oriented ethnic economy to find employment as their skills are not recognized or made use of in the high-skilled labor market. A more positive note is that a higher prevalence of overeducation compared to the native Dutch is not visible for secondgeneration Turkish and Moroccan men and for ethnic minority women. One explanation for this finding could be that first-generation immigrant women choose to focus on domestic tasks instead of working in a job that does not match their educational level. Moroccan and Turkish immigrant women often came as family migrants so their motivation to participate in the labor market may be lower than for the average native Dutch women. Among the second generation, those who obtain higher education may be perceived as particularly talented by Dutch employers because they counter the common stereotype of the low-achieving immigrant. Hence, employers who provide high-skilled level jobs may be as willing to hire them as Dutch majority applicants with similar educational achievements. This finding could also indicate that a lack of social capital may play a role in the first gen- eration's relatively higher probability of being overeducated. The second generation, while being subjected to similar stereotypes, tends to have more bridging ties to natives than the first generation, which might help them find occupations that match their level of education.

The results do not show substantial ethnic differences in undereducation. Only first-generation Moroccan women and non-Western origin men are somewhat less likely to be undereducated than the Dutch majority. The findings, therefore, provide little evidence for a positive selection of the examined immigrant groups.

I expected to find lower returns to foreign compared to Dutch education for ethnic minorities in general but especially for first generation Turks and Moroccans given that their origin countries' quality of education is often perceived as lower than Western countries' educational quality (Chiswick \& Miller, 2008; Friedberg, 2000). Among men, only first-generation Moroccans' labor market outcomes worsen (in terms of employment and overeducation) with a foreign compared to a Dutch degree. The fact that I do not find this negative relation for Turkish immigrants suggests that Moroccans with a foreign degree are selected on a particular characteristic that is detrimental for their labor market outcomes. Research on the immigrants' educational selectivity may provide further insights into differences between the Turkish and Moroccan community in the Netherlands (for immigrants' educational selectivity in France see Ichou, 2014). 
For women, foreign degrees make more of a difference than for men. I find lower employment probabilities of first generation Turkish and Non-Western women with a foreign degree compared to those with a domestic degree and higher probabilities of overeducation for Dutch majority and first generation Moroccan women with a foreign degree. Minority women who have invested in a Dutch degree after their arrival to the Netherlands may have more ambition and work commitment than those who have not made this investment. Furthermore, for work-oriented women, it may have been more difficult to obtain a degree in their origin country. It is somewhat puzzling to see difficulties in the international transferability of skills also among Dutch majority women. One explanation could be the field of study. Dutch women who study abroad may be more likely to study subjects that are difficult to transfer into a concrete profession, which may increase the probability to end up in a job below one's qualification. For future research of educationoccupation mismatches, it may, therefore, be fruitful to take into account field of study and type of occupation.

I find little evidence that ethnic minorities profit more from working in the public sector than in the private sector than the Dutch majority. In fact, evidence for lower overeducation probabilities in the public than in the private sector is clearer for the native Dutch than for some of the ethnic minority groups. This provides support for the more critical voices about the Dutch government's efforts to foster diversity within public administration (Vasta, 2007) Nonetheless, there are also some indications that Moroccan and Turkish women in the public sector are more likely to be undereducated than in the private sector, which could suggest that their abilities are more readily recognized in the public than in the private sector.

Of course, this study is not without limitations. In specific, small sample sizes reduce the reliability of some comparisons. For example, ethnic differences in labor market outcomes for the highly educated seem often substantial in their estimated size but are insignificant due to large confidence intervals. Moreover, the groups of non-Western and Western immigrants are rather heterogeneous, so it is not possible to infer any ethnicityspecific effects from their estimates. Studies with a larger sample of Surinamese, Antilleans, or any of the diverse groups of refugees may also offer useful comparisons to the findings of this study. Finally, the measure of education-occupation mismatches would also gain in precision with a larger sample.

The migration context in the Netherlands is comparable to many other European countries. For example, Turks and Moroccans in France and Germany migrated in the same historic period and for similar reasons as Turks in the Netherlands. They also share many socioeconomic characteristics. In comparison with other European countries, the presented findings may, therefore, also offer valuable insights into the potential impact of institutional factors on immigrants' returns to education.

\section{Acknowledgments}

This research and this thematic issue have been supported by funding from the European Commission (Grant number H2020 649255).

\section{Conflict of Interests}

The author declares no conflict of interests.

\section{References}

Aleksynska, M., \& Tritah, A. (2013). Occupationeducation mismatch of immigrant workers in Europe: Context and policies. Economics of Education Review, 36(C) 229-244. http://doi.org/10.1016/ j.econedurev.2013.06.001

Andriessen, I., Nievers, E., \& Dagevos, J. (2012). Op achterstand: Discriminatie van niet-westerse migranten op de arbeidsmarkt. The Hague: Sociaal en Cultureel Planbureau.

Baker, M., \& Benjamin, D. (1997). The role of the family in immigrants' labor market activity: An evaluation of alternative explanations. American Economic Review, 87(4), 705-727.

Becker, G. S. (1975). Human capital: A theoretical and empirical analysis, with special reference to education (2nd ed.). New York, NY: National Bureau of Economic Resaerch.

Bevelander, P., \& Veenman, J. (2004). Variation in perspective: The employment success of ethnic minority males in the Netherlands, 1988-2002. International Migration, 42(4), 35-64. http://doi.org/10.1111/ j.0020-7985.2004.00294.x

Bevelander, P., \& Veenman, J. (2006). Naturalisation and socioeconomic integration: The case of the Netherlands (IZA Discussion Paper no. 2153). Bonn: IZA.

Blau, F. D., Kahn, L. M., Moriarty, J. Y., \& Souza, A. P. (2003). The role of the family in immigrants' labor-market activity: An evaluation of alternative explanations. The American Economic Review, 93(1), 429-447.

Chiswick, B. R., \& Miller, P. W. (2008). Why is the payoff to schooling smaller for immigrants? Labour Economics, 15(6), 1317-1340. http://doi.org/10.1016/ J.LABECO.2008.01.001

Chiswick, B. R., \& Miller, P. W. (2009). The international transferability of immigrants' human capital. Economics of Education Review, 28, 162-169. http://doi.org/10.1016/j.econedurev.2008.07.002

Crul, M., \& Doomernik, J. (2003). The Turkish and Moroccan second generation in the Netherlands: Divergent trends between and polarization within the two groups. International Migration Review, 37(4), 1039-1064.

de Graaf, P. M., Kalmijn, M., Kraaykamp, G., \& Monden, C. W. S. (2010a). The NEtherlands longitudinal lifecourse study-NELLS Wave 1 (Dataset Report). The 
Netherlands: Tilburg University and Radboud University Nijmegen.

de Graaf, P. M., Kalmijn, M., Kraaykamp, G., \& Monden, C. W. S. (2010b). Design and content of the NEtherlands longitudinal lifecourse study-NELLS (Research Report). The Netherlands: Tilburg University and Radboud University Nijmegen.

Doomernik, J. (1998). The effectiveness of integration policies toward immigrants and their descendants in France, Germany and the Netherlands. Geneva: International Labor Organization.

Dourleijn, E., \& Dagevos, J. (2011). Vluchtelingengroepen in Nederland. The Hague: Sociaal en Cultureel Planbureau.

Dustmann, C., \& Fabbri, F. (2003). Language proficiency and labour market performance of immigrants in the UK. The Economic Journal, 113(489), 695-717. http://doi.org/10.1111/1468-0297.t01-1-00151

Fleming, C. M., \& Kler, P. (2008). I'm too clever for this job: A bivariate probit analysis on overeducation and job satisfaction in Australia. Applied Economics, 40, 1123-1138. http://doi.org/10.1080/ 00036840600771254

Friedberg, R. M. (2000). You can't take it with you? Immigrant assimilation and the portability of human capital. Journal of Labor Economics, 18(2), 221-251.

Gracia, P., Vázquez-Quesada, L., \& van de Werfhorst, H. G. (2016). Ethnic penalties? The role of human capital and social origins in labour market outcomes of second-generation Moroccans and Turks in the Netherlands. Journal of Ethnic and Migration Studies, 42(1), 69-87. http://doi.org/10.1080/ 1369183X.2015.1085800

Groeneveld, S. (2011). Diversity and employee turnover in the Dutch public sector. International Journal of Public Sector Management, 24(6), 594-612. http:// doi.org/10.1108/09513551111163675

Hainmueller, J., Pietrantuono, G., Aktas, M., Balaban, D., \& Kurer, S. (2017). Catalyst or crown: Does naturalization promote the long-term social integration of immigrants? American Political Science Review, 111(2), 256-276. http://doi.org/10.1017/ S0003055416000745

Hardoy, I., \& Schøne, P. (2014). Returns to preimmigration education for non-western immigrants: Why so low? Education Economics, 22(1), 48-72. http://doi.org/10.1080/09645292.2010.511846

Hartog, J. (2000). Over-education and earnings: Where are we, where should we go? Economics of Education Review, 19(2), 131-147. http://doi.org/10.1016/ S0272-7757(99)00050-3

Heath, A. F., Rothon, C., \& Kilpi, E. (2008). The second generation in Western Europe: Education, unemployment, and occupational attainment. Annual Review of Sociology, 34(1), 211-235. http://doi.org/ 10.1146/annurev.soc.34.040507.134728

Huijnk, W., \& Andriessen, I. (2016). Integratie inzicht?
De integratie van migranten in Nederland op acht terreinen nader bekeken. The Hague: Sociaal en Cultureel Planbureau.

Ichou, M. (2014). Who they were there: Immigrants' educational selectivity and their children's educational attainment. European Sociological Review, 30(6), 750-765. http://doi.org/10.1093/esr/jcu071

Lancee, B. (2010). The economic returns of immigrants' bonding and bridging social capital: The case of the Netherlands. International Migration Review, 44(1), 202-226. http://doi.org/10.1111/j.17477379.2009.00803.x

Li, Q., \& Sweetman, A. (2014). The quality of immigrant source country educational outcomes: Do they matter in the receiving country? Labour Economics, 26, 81-93. http://doi.org/10.1016/j.labeco.2013.12.003

Michon, L., \& Vermeulen, F. (2013). Explaining different trajectories in immigrant political integration: Moroccans and Turks in Amsterdam. West European Politics, 36(3), 597-614. http://doi.org/ 10.1080/01402382.2013.773727

Nielsen, C. P. (2011). Immigrant over-education: Evidence from Denmark. Journal of Population Economics, 24(2), 499-520. http://doi.org/10.1007/ s00148-009-0293-0

Portes, A., \& Zhou, M. (1993). The new second generation: Segmented assimilation and its variants segmented assimilation and its variants. The Annals of the American Academy of Political and Social Science, 530, 74-96.

Tesser, P. T. M., \& Veenman, J. (1997). Rapportage minderheden 1997. The Hague: Sociaal en Cultureel Planbureau.

van de Werfhorst, H. G., \& van Tubergen, F. (2007). Ethnicity, schooling, and merit in the Netherlands. Ethnicities, 7(3), 416-444. http://doi.org/10.1177/ 1468796807080236

Vasta, E. (2007). From ethnic minorities to ethnic majority policy: Multiculturalism and the shift to assimilationism in the Netherlands. Ethnic and Racial Studies, 30(5), 713-740. http://doi.org/10.1080/ 01419870701491770

Verhaest, D., \& Omey, E. (2006). Measuring the incidence of over-and undereducation. Quality \& Quantity, 40, 783-803. http://doi.org/10.1007/s11135-005-39553

Witteveen, D., \& Alba, R. (2017). Labour market disadvantages of second-generation Turks and Moroccans in the Netherlands: Before and during the Great Recession. International Migration. http://doi.org/ 10.1111/imig.12411

Zschirnt, E., \& Ruedin, D. (2016). Ethnic discrimination in hiring decisions: A meta-analysis of correspondence tests 1990-2015. Journal of Ethnic and Migration Studies, 42(7), 1115-1134. http:// doi.org/10.1080/1369183X.2015.1133279 


\section{About the Author}

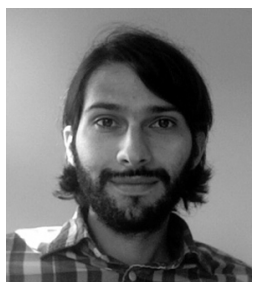

Yassine Khoudja is a Post-Doctoral Researcher at the European Research Center on Migration and Ethnic Relations (ERCOMER) at Utrecht University. His main research interests are situated in the fields of immigrant integration, cultural diversity, and gender inequality. He wrote his dissertation about women's labor market participation across ethnic groups in Western Europe, focusing on the role of gender role attitudes, religiosity and household conditions. 
Annex

Table A1. Logit regression of employment for men and for women.

\begin{tabular}{|c|c|c|c|c|}
\hline & \multicolumn{2}{|c|}{ MEN } & \multicolumn{2}{|c|}{ WOMEN } \\
\hline & $\begin{array}{l}\text { Employment: } \\
\text { Basic model }\end{array}$ & $\begin{array}{l}\text { Employment: } \\
\text { Extensive model }\end{array}$ & $\begin{array}{l}\text { Employment: } \\
\text { Basic model }\end{array}$ & $\begin{array}{l}\text { Employment: } \\
\text { Extensive model }\end{array}$ \\
\hline \multirow[t]{2}{*}{ Age } & $0.02 *$ & $0.03 *$ & 0.00 & 0.01 \\
\hline & $(0.01)$ & $(0.01)$ & $(0.01)$ & $(0.01)$ \\
\hline \multirow[t]{2}{*}{ Age squared } & $-0.00 * * *$ & $-0.00 * * *$ & $-0.00 *$ & $-0.00 *$ \\
\hline & $(0.00)$ & $(0.00)$ & $(0.00)$ & $(0.00)$ \\
\hline \multirow[t]{2}{*}{ Years of education } & $0.10 * * *$ & $0.09 * * *$ & $0.19 * * *$ & $0.18 * * *$ \\
\hline & $(0.03)$ & $(0.03)$ & $(0.02)$ & $(0.02)$ \\
\hline \multirow[t]{2}{*}{ Years since migration } & -0.01 & -0.02 & $0.04 * * *$ & $0.03 * *$ \\
\hline & $(0.01)$ & $(0.01)$ & $(0.01)$ & $(0.01)$ \\
\hline \multirow{2}{*}{$\begin{array}{l}\text { Lives in big or medium city } \\
\qquad(0=\text { lives in town or rural area) }\end{array}$} & & -0.15 & & 0.08 \\
\hline & & $(0.18)$ & & $(0.13)$ \\
\hline \multirow{2}{*}{$\begin{array}{l}\text { No Dutch language proficiency } \\
\text { ( } 0=\text { proficient in Dutch) }\end{array}$} & & $-0.63^{*}$ & & $-0.55^{*}$ \\
\hline & $(0.25)$ & & $(0.22)$ & \\
\hline \multirow[t]{2}{*}{ Foreign citizenship ( $0=$ Dutch citizenship) } & & 0.21 & & $-0.52 *$ \\
\hline & & $(0.25)$ & & $(0.20)$ \\
\hline \multicolumn{5}{|l|}{ Origin group (0 = Dutch majority) } \\
\hline \multirow[t]{2}{*}{ 1st gen Moroccan } & $-1.13 * * *$ & $-0.94 *$ & $-2.76 * * *$ & $-2.23 * * *$ \\
\hline & $(0.32)$ & $(0.38)$ & $(0.26)$ & $(0.30)$ \\
\hline \multirow{2}{*}{ 2nd gen Moroccan } & $-1.37 * * *$ & $-1.31 * * *$ & $-1.01 * * *$ & $-0.98 * * *$ \\
\hline & $(0.27)$ & $(0.28)$ & $(0.23)$ & $(0.23)$ \\
\hline \multirow{2}{*}{ 1st gen Turk } & $-0.67^{*}$ & -0.45 & $-2.50 * * *$ & $-1.90 * * *$ \\
\hline & $(0.31)$ & $(0.39)$ & $(0.26)$ & $(0.31)$ \\
\hline \multirow[t]{2}{*}{ 2nd gen Turk } & $-1.30 * * *$ & $-1.23 * * *$ & $-0.94 * * *$ & $-0.93 * * *$ \\
\hline & $(0.26)$ & $(0.27)$ & $(0.23)$ & $(0.23)$ \\
\hline \multirow[t]{2}{*}{ 1st \& 2nd gen Non-Western } & $-1.20 * * *$ & $-1.05^{* *}$ & $-1.42 * * *$ & $-1.16^{* * *}$ \\
\hline & $(0.36)$ & $(0.38)$ & $(0.30)$ & $(0.31)$ \\
\hline \multirow[t]{2}{*}{ 1st \& 2nd gen Western } & $-0.91^{*}$ & $-0.86^{*}$ & $-1.34 * * *$ & $-1.09 * * *$ \\
\hline & $(0.43)$ & $(0.44)$ & $(0.31)$ & $(0.31)$ \\
\hline \multirow[t]{2}{*}{ Constant } & $1.76 * * *$ & $1.92 * * *$ & -0.18 & -0.04 \\
\hline & $(0.38)$ & $(0.39)$ & $(0.28)$ & (0.29) \\
\hline $\mathrm{N}$ & 1975 & 1975 & 2231 & 2230 \\
\hline Log likelihood & -707.97 & -703.86 & -929.50 & -920.15 \\
\hline chi2 & 104.13 & 114.62 & 351.48 & 338.18 \\
\hline
\end{tabular}

Notes: Standard errors in parentheses; ${ }^{*} p<0.05,{ }^{* *} p<.01,{ }^{* * *} p<.001$ 
Table A2. Logit regressions of overeducation for men and women.

\begin{tabular}{|c|c|c|c|c|}
\hline & \multicolumn{2}{|c|}{ MEN } & \multicolumn{2}{|c|}{ WOMEN } \\
\hline & $\begin{array}{l}\text { Overeducation: } \\
\text { Basic model }\end{array}$ & $\begin{array}{l}\text { Overeducation: } \\
\text { Extensive model }\end{array}$ & $\begin{array}{l}\text { Overeducation } \\
\text { Basic model }\end{array}$ & $\begin{array}{l}\text { Overeducation } \\
\text { Extensive model }\end{array}$ \\
\hline Age & $\begin{array}{c}-0.07^{*} \\
(0.03)\end{array}$ & $\begin{array}{l}-0.05 \\
(0.03)\end{array}$ & $\begin{array}{l}-0.07 \\
(0.05)\end{array}$ & $\begin{array}{l}-0.00 \\
(0.05)\end{array}$ \\
\hline Age squared & $\begin{array}{c}0.00 \\
(0.00)\end{array}$ & $\begin{array}{c}0.00 \\
(0.00)\end{array}$ & $\begin{array}{c}0.00 \\
(0.00)\end{array}$ & $\begin{array}{c}0.00 \\
(0.00)\end{array}$ \\
\hline Years of education & $\begin{array}{c}0.96 * * * \\
(0.07)\end{array}$ & $\begin{array}{c}0.94 * * * \\
(0.07)\end{array}$ & $\begin{array}{l}0.95 * * * \\
(0.07)\end{array}$ & $\begin{array}{c}0.92 * * * \\
(0.07)\end{array}$ \\
\hline Exposure to Dutch labor market & $\begin{array}{c}0.05 \\
(0.03)\end{array}$ & $\begin{array}{c}0.03 \\
(0.03)\end{array}$ & $\begin{array}{c}0.05 \\
(0.04)\end{array}$ & $\begin{array}{l}-0.02 \\
(0.04)\end{array}$ \\
\hline $\begin{array}{l}\text { Lives in big or medium city } \\
\qquad(0=\text { lives in town or rural area) }\end{array}$ & & $\begin{array}{c}0.17 \\
(0.24)\end{array}$ & & $\begin{array}{l}-0.51 \\
(0.26)\end{array}$ \\
\hline $\begin{array}{l}\text { No Dutch language proficiency } \\
(0=\text { proficient in Dutch) }\end{array}$ & & $\begin{array}{c}0.00 \\
(0.59)\end{array}$ & & $\begin{array}{l}1.48^{*} \\
(0.72)\end{array}$ \\
\hline Foreign citizenship ( $0=$ Dutch citizenship) & & $\begin{array}{l}-0.54 \\
(0.35)\end{array}$ & & $\begin{array}{l}-0.81 \\
(0.58)\end{array}$ \\
\hline Origin group ( $0=$ Dutch majority) & & & & \\
\hline 1st gen Moroccan & $\begin{array}{c}1.33^{* * *} \\
(0.29)\end{array}$ & $\begin{array}{c}1.16 * * * \\
(0.31)\end{array}$ & $\begin{array}{c}0.38 \\
(0.39)\end{array}$ & $\begin{array}{c}0.28 \\
(0.49)\end{array}$ \\
\hline 2nd gen Moroccan & $\begin{array}{l}-0.73 \\
(0.62)\end{array}$ & $\begin{array}{l}-0.80 \\
(0.63)\end{array}$ & $\begin{array}{c}0.03 \\
(0.38)\end{array}$ & $\begin{array}{c}0.11 \\
(0.42)\end{array}$ \\
\hline 1st gen Turk & $\begin{array}{c}1.00 * * \\
(0.32)\end{array}$ & $\begin{array}{l}0.80 * \\
(0.35)\end{array}$ & $\begin{array}{c}0.26 \\
(0.48)\end{array}$ & $\begin{array}{c}0.19 \\
(0.45)\end{array}$ \\
\hline 2nd gen Turk & $\begin{array}{c}0.70 \\
(0.45)\end{array}$ & $\begin{array}{c}0.63 \\
(0.46)\end{array}$ & $\begin{array}{l}-0.93 \\
(0.63)\end{array}$ & $\begin{array}{l}-0.81 \\
(0.66)\end{array}$ \\
\hline 1st \& 2nd gen Non-Western & $\begin{array}{c}0.31 \\
(0.50)\end{array}$ & $\begin{array}{c}0.33 \\
(0.50)\end{array}$ & $\begin{array}{l}-0.47 \\
(0.66)\end{array}$ & $\begin{array}{l}-0.31 \\
(0.69)\end{array}$ \\
\hline 1st \& 2nd gen Western & $\begin{array}{l}-0.59 \\
(0.46)\end{array}$ & $\begin{array}{l}-0.69 \\
(0.48)\end{array}$ & $\begin{array}{l}-0.57 \\
(0.77)\end{array}$ & $\begin{array}{l}-0.70 \\
(0.75)\end{array}$ \\
\hline Constant & $\begin{array}{c}-15.93^{* * *} \\
(1.19)\end{array}$ & $\begin{array}{c}-14.94 * * * \\
(1.28)\end{array}$ & $\begin{array}{c}-15.87^{* * *} \\
(1.42)\end{array}$ & $\begin{array}{c}-13.51^{* * *} \\
(1.65)\end{array}$ \\
\hline $\mathrm{N}$ & 1715 & 1715 & 1619 & 1619 \\
\hline Log likelihood & -370.03 & -368.73 & -274.16 & -268.65 \\
\hline chi2 & 265.02 & 264.78 & 248.88 & 250.74 \\
\hline
\end{tabular}

Notes: Standard errors in parentheses; ${ }^{*} p<0.05,{ }^{* *} p<.01,{ }^{* * *} p<.001$ 
Table A3. Logit regressions of undereducation for men and women.

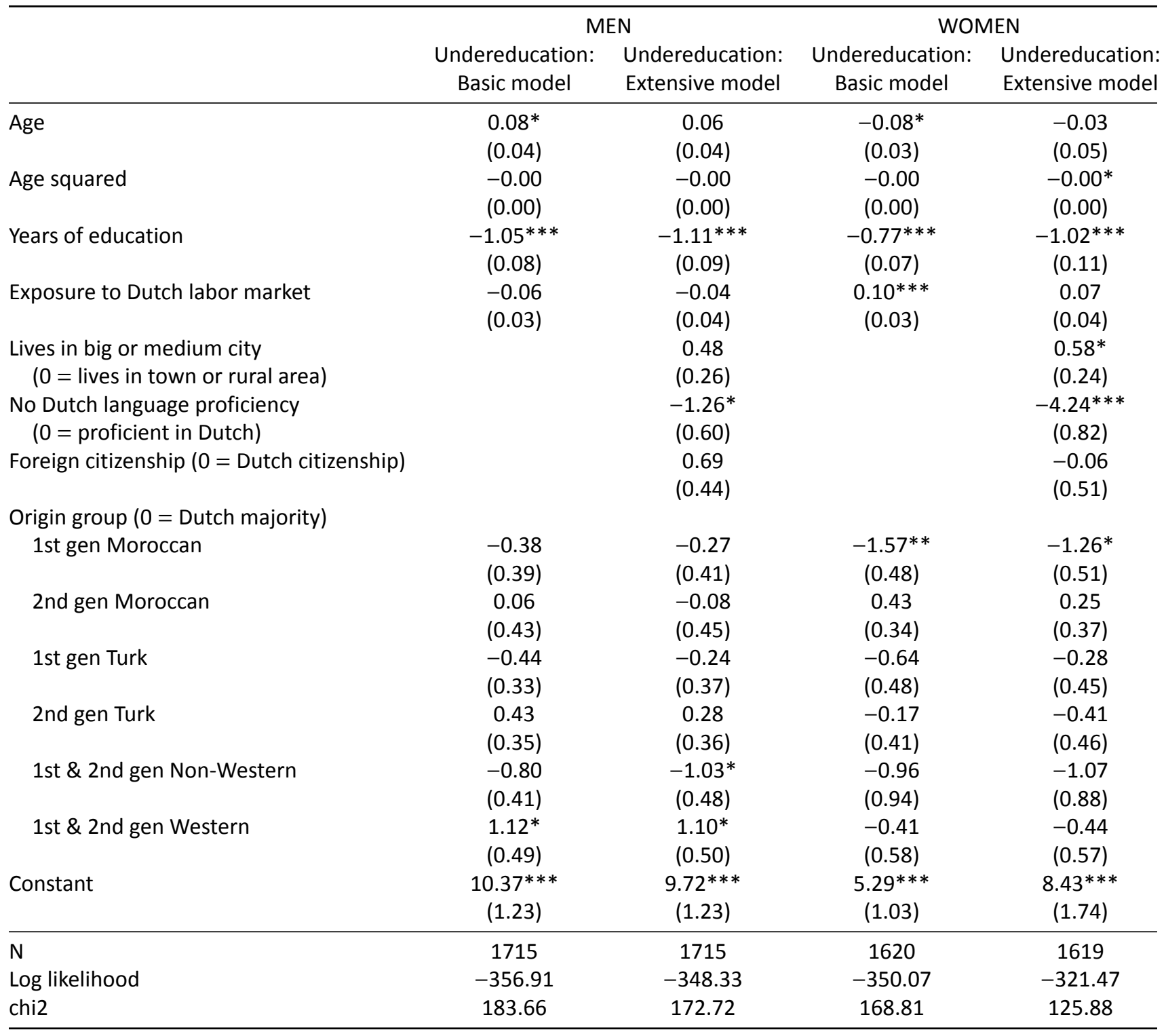

Notes: Standard errors in parentheses; ${ }^{*} p<0.05,{ }^{* *} p<.01,{ }^{* * *} p<.001$ 
Table A4. Logit regressions on undereducation for men and women.

\begin{tabular}{|c|c|c|c|c|c|c|}
\hline & $\begin{array}{c}\text { Labor } \\
\text { force } \\
\text { participation }\end{array}$ & $\begin{array}{c}\text { MEN } \\
\text { Employment } \\
\text { (excl. } \\
\text { inactive) }\end{array}$ & $\begin{array}{l}\text { Employment } \\
\text { (incl. } \\
\text { inactive) }\end{array}$ & $\begin{array}{c}\text { Labor } \\
\text { force } \\
\text { participation }\end{array}$ & $\begin{array}{l}\text { WOMEN } \\
\text { Employment } \\
\text { (excl. } \\
\text { inactive) }\end{array}$ & $\begin{array}{l}\text { Employment } \\
\text { (incl. } \\
\text { inactive) }\end{array}$ \\
\hline \multirow[t]{2}{*}{ Age } & 0.00 & $0.05 * * *$ & $0.03^{*}$ & -0.01 & $0.04 * *$ & 0.01 \\
\hline & $(0.01)$ & $(0.01)$ & $(0.01)$ & $(0.01)$ & $(0.01)$ & $(0.01)$ \\
\hline \multirow[t]{2}{*}{ Age squared } & $-0.00 * *$ & -0.00 & $-0.00 * * *$ & -0.00 & $-0.00 *$ & $-0.00^{*}$ \\
\hline & $(0.00)$ & $(0.00)$ & $(0.00)$ & $(0.00)$ & $(0.00)$ & $(0.00)$ \\
\hline \multirow[t]{2}{*}{ Years of education } & $0.11^{* *}$ & 0.07 & $0.09 * * *$ & $0.17 * * *$ & $0.13 * * *$ & $0.18^{* * *}$ \\
\hline & $(0.03)$ & $(0.04)$ & $(0.03)$ & $(0.02)$ & $(0.03)$ & $(0.02)$ \\
\hline \multirow[t]{2}{*}{ Years since migration } & 0.01 & $-0.04^{*}$ & -0.02 & $0.02 *$ & 0.02 & $0.03^{* *}$ \\
\hline & $(0.02)$ & $(0.02)$ & $(0.01)$ & $(0.01)$ & $(0.02)$ & $(0.01)$ \\
\hline \multirow{2}{*}{$\begin{array}{l}\text { Lives in big or medium city } \\
(0=\text { lives in town or } \\
\text { rural area) }\end{array}$} & -0.22 & -0.06 & -0.15 & 0.04 & 0.11 & 0.08 \\
\hline & $(0.25)$ & $(0.24)$ & $(0.18)$ & $(0.15)$ & $(0.20)$ & $(0.13)$ \\
\hline \multirow{2}{*}{$\begin{array}{l}\text { No Dutch language proficiency } \\
(0=\text { proficient in Dutch) }\end{array}$} & -0.47 & $-0.78^{*}$ & $-0.63^{*}$ & $-0.62 * *$ & -0.12 & $-0.55^{*}$ \\
\hline & $(0.35)$ & $(0.33)$ & $(0.25)$ & $(0.22)$ & $(0.38)$ & $(0.22)$ \\
\hline \multirow{2}{*}{$\begin{array}{l}\text { Foreign citizenship } \\
\qquad(0=\text { Dutch citizenship) }\end{array}$} & -0.20 & -0.22 & -0.21 & $0.55^{* *} 0.21$ & $0.52 *$ & \\
\hline & $(0.36)$ & $(0.32)$ & $(0.25)$ & $(0.21)$ & $(0.34)$ & $(0.20)$ \\
\hline \multicolumn{7}{|l|}{ Origin group } \\
\hline \multicolumn{7}{|l|}{ (0 = Dutch majority) } \\
\hline \multirow[t]{2}{*}{ 1st gen Moroccan } & $-1.04^{*}$ & -0.71 & $-0.94^{*}$ & $-2.08 * * *$ & $-1.79 * * *$ & $-2.23 * * *$ \\
\hline & $(0.52)$ & $(0.50)$ & $(0.38)$ & $(0.33)$ & $(0.47)$ & $(0.30)$ \\
\hline \multirow[t]{2}{*}{ 2nd gen Moroccan } & $-1.31 * * *$ & $-1.24 * *$ & $-1.31 * * *$ & $-1.06 * * *$ & -0.67 & $-0.98 * * *$ \\
\hline & $(0.37)$ & $(0.39)$ & $(0.28)$ & $(0.26)$ & $(0.40)$ & $(0.23)$ \\
\hline \multirow[t]{2}{*}{ 1st gen Turk } & -0.69 & -0.19 & -0.45 & $-1.56 * * *$ & $-2.12 * * *$ & $-1.90 * * *$ \\
\hline & $(0.53)$ & $(0.51)$ & $(0.39)$ & $(0.34)$ & $(0.52)$ & $(0.31)$ \\
\hline \multirow[t]{2}{*}{ 2nd gen Turk } & $-1.33 * * *$ & $-1.06 * *$ & $-1.23 * * *$ & -0.44 & $-1.46 * * *$ & $-0.93 * * *$ \\
\hline & $(0.36)$ & $(0.37)$ & $(0.27)$ & $(0.29)$ & $(0.32)$ & $(0.23)$ \\
\hline \multirow[t]{2}{*}{ 1st \& 2nd gen Non-Western } & $-1.18^{*}$ & -0.79 & $-1.05^{* *}$ & $-0.88^{*}$ & $-1.43 * * *$ & $-1.16 * * *$ \\
\hline & $(0.55)$ & $(0.47)$ & $(0.38)$ & $(0.36)$ & $(0.43)$ & $(0.31)$ \\
\hline \multirow[t]{2}{*}{ 1st \& 2nd gen Western } & -1.02 & -0.61 & $-0.86^{*}$ & $-0.83^{*}$ & $-1.41 * *$ & $-1.09 * * *$ \\
\hline & $(0.55)$ & $(0.67)$ & $(0.44)$ & $(0.33)$ & $(0.52)$ & $(0.31)$ \\
\hline \multirow[t]{2}{*}{ Constant } & $2.76 * * *$ & $3.04 * * *$ & $2.13^{* * *}$ & -0.18 & $1.59 *$ & -0.56 \\
\hline & $(0.60)$ & $(0.59)$ & $(0.44)$ & $(0.36)$ & $(0.62)$ & $(0.35)$ \\
\hline $\mathrm{N}$ & 1975 & 1839 & 1975 & 2230 & 1760 & 2230 \\
\hline
\end{tabular}

Notes: Standard errors in parentheses; ${ }^{*} p<0.05,{ }^{* *} p<.01,{ }^{* * *} p<.001$ 


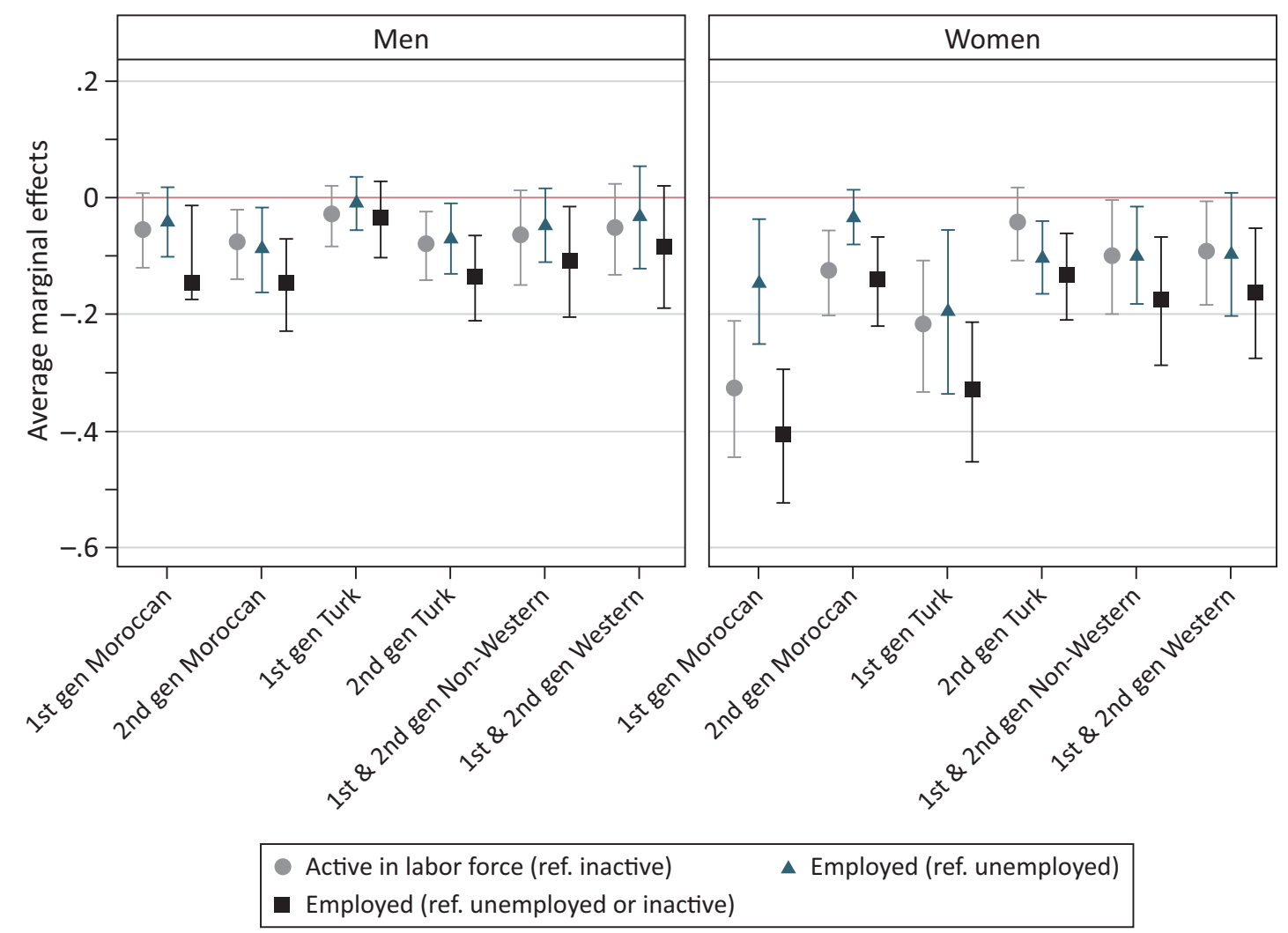

Figure A1. Gaps in labor market outcomes by ethnicity and generation. Models are weighted and account for age, age square, years of education, years since migration, urbanity, language problems, and Dutch citizenship (see Table A4).

Additional robustness checks for selection bias. To test whether selection into employment biases the results presented in the main analysis, I estimate the over- and undereducation with the extensive controls (age, age square, exposure to Dutch labor market, urbanity, Dutch language problems, and Dutch citizenship) using Heckman correction. I use the heckprobit procedure in Stata 13. The heckprobit models consist of one equation with the dependent variable of interest, in this case overeducation or undereducation, and a selection equation that predicts selection into the main outcome, in this case employment. The selection equation requires in addition to the main controls at least one instrument, i.e., a variable related to the selection but not to the main outcome. Potential instruments are partnership status and the presence of young children because they are unlikely to be related to education-occupation mismatches while they are established predictors of employment. Both variables have been used as instruments in earlier studies (Jauhiainen, 2011; Piracha, Tani, \& Matloub, 2012). To test the assumption that partnership status and children are unrelated to the outcome, I estimated logit regressions of over and undereducation with these predictors added to the extensive model of the main analysis. I find that living with a partner is indeed unrelated to education-occupation mismatches for both men and women. This applies to the presence of children as well with the exception of women's undereducation, for which the presence of young children is a significant predictor. To avoid misspecification, I, therefore, use only living with a partner as an additional predictor in the selection equation for women's undereducation. I use living with a partner and the presence of young children as additional predictors in the selection equation for women's and men' overeducation, and for men's undereducation. I have also considered using district unemployment rates and district welfare recipient rates as instruments, but both were not associated with employment probabilities. Results are shown in Figure A2 for overeducation, and Figure A3 for undereducation. Overall, results are very similar regardless of whether Heckman correction was used or not. The main difference that can be observed is the larger confidence intervals, particularly in the estimates for overeducation. However, the observed differences do not lead to substantively different conclusions. 

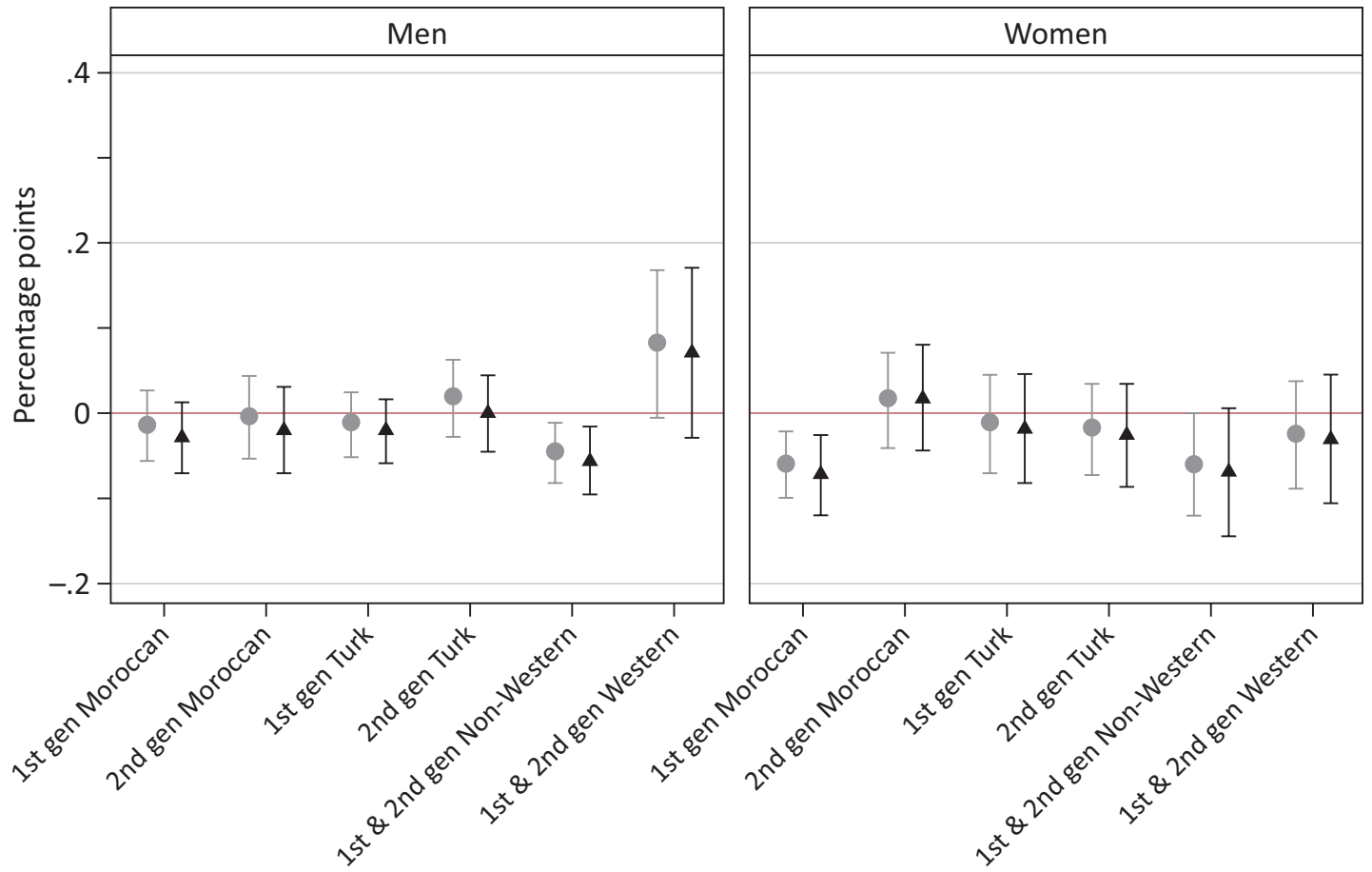

No heckprob selection

A Heckprob selection

Figure A2. Estimated gaps in overeducation between different origin groups and Dutch majority with $95 \%$ (c.i.) using Heckman correction. Models estimated with robust standard errors. Circles show same estimates as extensive model in Figure 2. Triangle shows estimates of the same model with Heckman correction.
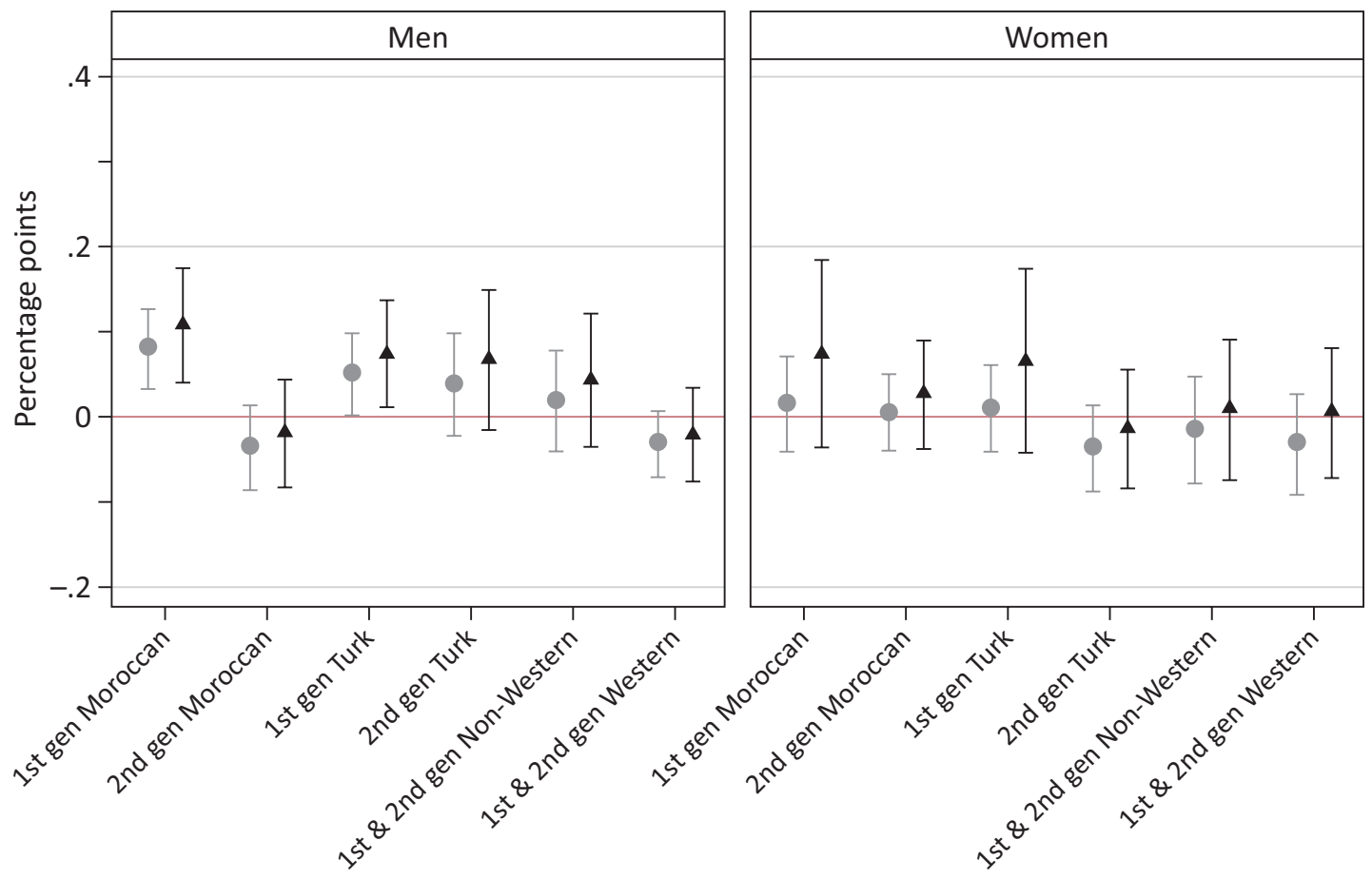

No heckprob selection $\quad \Delta$ Heckprob selection

Figure A3. Estimated gaps in undereducation between different origin groups and Dutch majority with $95 \%$ (c.i.) using Heckman correction. Models estimated with robust standard errors. Circles show same estimates as extensive model in Figure 3. Triangles show estimates of the same model with Heckman correction. 


\section{References}

Jauhiainen, S. (2011). Overeducation in the Finnish regional labour markets. Papers in Regional Science, 90(3), 573-588. http://doi.org/10.1111/j.1435-5957.2010.00334.x

Piracha, M., Tani, M., \& Vadean, F. (2012). Immigrant over-and under-education: The role of home country labour market experience. IZA Journal of Migration, 1(3). 